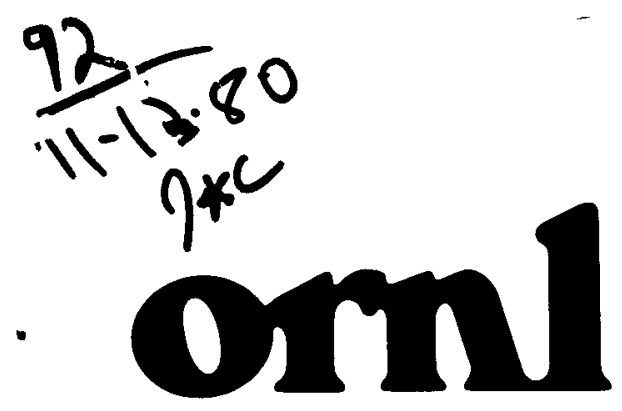

OAK RIDGE NATIONAL LABORATORY

UNION CARBIDE
MASTER

ORNL/TM-7108

\title{
Thorex Solvent Extraction Studies with Irradiated HTGR Fuel: Series I
}

\author{
C. E. Lamb \\ A. D. Mitchell \\ V. C. A. Vaughen \\ R. J. Shannon
}

This document is PUBLICLY RELEASABLE

Dave Hamrin, ORNL
Authorizing Official
Date $\quad 1-11-12$

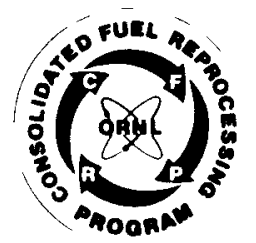

\section{OPERATED BY}

UNION CARBIDE CORPORATION FOR THE UNITED STATES DEPARTMENT OF ENERGY 


\section{DISCLAIMER}

This report was prepared as an account of work sponsored by an agency of the United States Government. Neither the United States Government nor any agency Thereof, nor any of their employees, makes any warranty, express or implied, or assumes any legal liability or responsibility for the accuracy, completeness, or usefulness of any information, apparatus, product, or process disclosed, or represents that its use would not infringe privately owned rights. Reference herein to any specific commercial product, process, or service by trade name, trademark, manufacturer, or otherwise does not necessarily constitute or imply its endorsement, recommendation, or favoring by the United States Government or any agency thereof. The views and opinions of authors expressed herein do not necessarily state or reflect those of the United States Government or any agency thereof. 


\section{DISCLAIMER}

Portions of this document may be illegible in electronic image products. Images are produced from the best available original document. 
Printed in the United States of America. Avarlable from the Department of Energy

Technical Information Center

P.O. Box 62, Oak Ridge, Tennessee 37830

This report was prepared as an account of work sponsored by an agency of the United States Government Neither the United States Government nor any agency thereof, nor any of their employees, makes any warranty, express or implied, or assumes any legal liability or responsibility for the accuracy, completeness, or usefulness of any information, apparatus, product, or process disclosed, or represents that its use would not infringe privately owned rights Reference herein to any specific commercial product, process, or service by trade name, trademark, manufacturer, or otherwise. does not necessarily constitute or imply its endorsement, recommendation, or favoring by the United States Government or any agency thereof The views and opinions of authors expressed herein do not necessarily state or reflect those of the United States Government or any agency thereof 


\author{
ORNL/TM-7108 \\ Dist. Category UC-86 \\ (Applied)
}

Contract No. W-7405-eng-26

Consolidated Fuel Reprocessing Program

THOREX SOLVENT EXTRACTION STUDIES WITH IRRADIATED HTGR FUEL: SERIES I

\author{
C. E. Lamb \\ A. D. Mitche11 \\ V. C. A. Vaughen \\ R. J. Shannon
}

Chemical Technology Division

Date Published: October 1980

NOTICE: This document contains information of a preliminary nature. It is subject to revision or correction and therefore does not represent a final report.

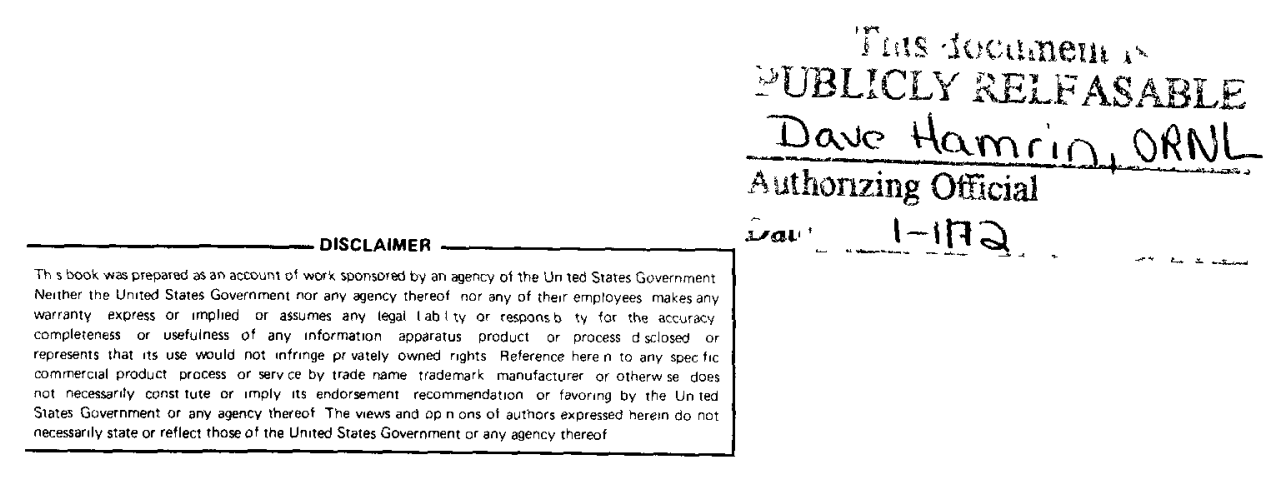

OAK RIDGE NATIONAL LABORATORY

Oak Ridge, Tennessee 37830

operated by

UNION CARBIDE CORPORATION

for the DEPARTMENT OF ENERGY

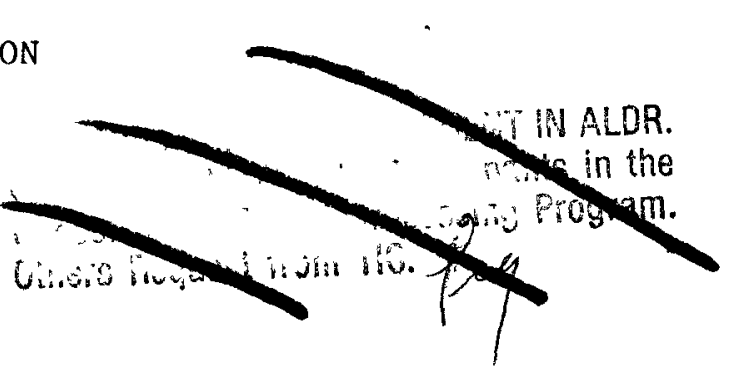




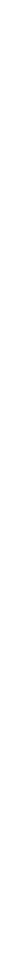


TABLE OF CONTENTS

\section{Page}

LIST OF TABLES . . . . . . . . . . . . . . . iv LIST OF FIGURES . . . . . . . . . . . . . . . v ABSTRACT . . . . . . . . . . . . . . . 1

1. InTROdUCtION ...................... 1

2. EQUIPMENT ................. 5

3. SOLUTIONS .................... 6

4. EXPERIMENTAL ................ 6

4.1 Extraction Column ............. 8

4.2 Partition Column ............. 19

4.3 Partition-Scrub Column ............ 19

4.4 Strip Column .................. 25

4.5 Fission Product Distribution.......... 30

5. EVALUATION OF THE PERFORMANCE OF THE SEPHIS-MOD4 CODE • 34

6. CONCLUSIONS AND RECOMMENDATIONS . . . . . . . . 34

7. ACKNOWLEDGMENTS ............. 37

8. REFERENCES .......................... 38 
1. First-cycle specifications ............. 3

2. Feed (1AF) criteria/composition ........... 7

3. Material balances for the cold extraction test, experiment 12, 1A column .............. 10

4. Comparison of analytical values with SEPHIS predictions for cold extraction test, experiment 12, 1A column . . 12

5. Distribution coefficients for cold extraction test, experiment 12, 1A column .............. 13

6. Comparison of analytical values with SEPHIS predictions for hot extraction test, experiment 13, 1A column . . 16

7. Comparison of analytical values with SEPHIS predictions for cold partition test, experiment 4, 1BX column . . 20

8. Comparison of analytical values with SEPHIS predictions for hot partition test, experiment 14, 1BX column .. 21

9. Comparison of analytical values with SEPHIS predictions for cold partition-scrub test, experiment $5,1 B S$ column..................... 24

10. Comparison of analytical values with SEPHIS predictions for hot partition-scrub test, experiment 15, 1BS column .................... 26

11. Comparison of analytical values with SEPHIS predictions for cold strip test, experiment $6,1 \mathrm{c}$ column ..... 28

12. Comparison of analytical values with SEPHIS predictions for hot strip test, experiment 16, 1C column ..... 29

13. Distribution and accountability of the plutonium in the hot experiments ............... 31 
LIST OF FIGURES

FIGURE

PAGE

1. Acld thorex process: first cycle proposed by General

Atomic Company .................. 2

2. Schematic diagram of the cold extraction test, experiment 12, $1 \mathrm{~A}$ column . . . . . . . . . . 9

3. Schematic diagram of the hot extraction test, experiment 13, 1A column ............. 14

4. McCabe-Thiele diagram for cold extraction test, experiment $12,1 \mathrm{~A}$ column .............

5. McCabe-Thiele diagram for hot extraction test, experiment $13,1 \mathrm{~A}$ column. Data points are identified by contact numbers (see Fig. 3) . . . . . . . .

6. McCabe-Thiele diagram for cold partition test, experiment 4, 1BX column . . . . . . . . . 22

7. McCabe-Thiele diagram for hot partition test, experiment 14, 1BX column ........... 23

8. McCabe-Thiele diagram for hot partition-scrub test, experiment 15 , IBS column ............

9. Plutonium distribution between the organic and aqueous phases...................

10. Extraction column (experiment 13, 1A column): heavymetal and radionuclide distribution (first stage)...

11. Partition column (experiment 14, 1BX column): heavymetal and radionuclide distribution (first stage)....

12. Partition-scrub column (experiment 15, 1BS column): heavy-metal and radionuclide distribution (first stage). 
ORNL/TM-7108

Dist. Category UC-86

(Applied)

THOREX SOLVENT EXTRACTION STUDIES WITH IRRADIATED HTGR FUEL: SERIES I

C. E. Lamb*

A. D. Mitche 11 *

V. C. A. Vaughen*

R. J. Shannon*

Consolidated Fuel Reprocessing Program

ABSTRACT

A series of solvent extraction experiments to test the firstcycle fuel reprocessing flowsheet, proposed by the General Atomic Company for the Hot Engineering Test Facllity, was completed. Using irradiated fuel, the experiments were designed to test the extraction, partition, partition-scrub, and strip operations. Each experiment utilized crosscurrent batch extractions and consecutive stages. Each stage was tested in duplicate.

Experimental procedures were developed with synthetic feeds and then were used in a hot cell with radioactive solutions of dissolved irradiated fuel. The analytical measurements for thorium and acid compared favorably with the values predicted by the computer program for solvent extraction processes having interacting solutes (SEPHIS-MOD4).

The SEPHIS-MOD4 program was valuable in interpreting this first set of experiments with irradiated fuels. Significant problems were experienced in the analysis for uranium in irradiated solutions. These problems emphasize the need for continued development of new or improved procedures for analyzing highly radioactive materials.

\section{INTRODUCTION}

The initial series of experiments to test the first-cycle fuel reprocessing flowsheet (Fig. 1), as proposed by the General Atomic Company for the Hot Engineering Test Facility, was completed using irradiated fuel. The experiments were designed to test the solvent extraction conditions listed in Table 1 for the extraction (1A), partition (1BX), partition-scrub (1BS), and strip operations (1C). The process utilizes "pulse" columns for contacting the aqueous and organic streams. Each column contains an internal assembly of perforated metal plates spaced along its length. The plates form stages that mix the aqueous and organic solutions as they flow countercurrent through the column. 
ORNL OWG $79-747 R 2$

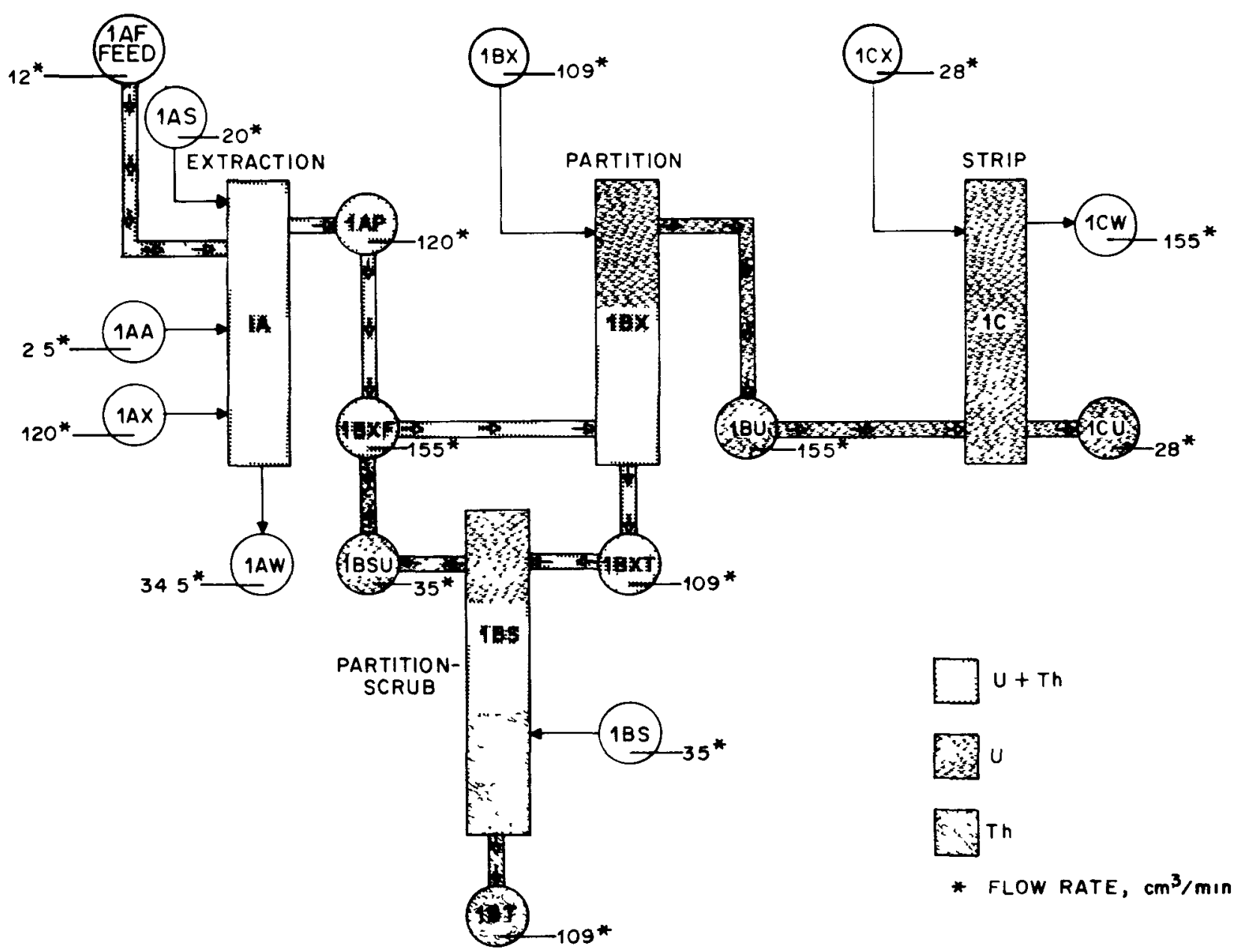

Fig. 1. Acid thorex process: first cycle proposed by General Atomic Company. 
Table 1. First-cycle specifications

\begin{tabular}{|c|c|c|c|c|c|c|c|c|c|c|c|c|c|c|c|c|}
\hline \multirow[t]{3}{*}{ Operation: } & \multicolumn{5}{|c|}{ Extraction } & 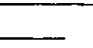 & \multicolumn{4}{|c|}{ Partition } & \multicolumn{3}{|c|}{ Partition-scrub } & \multicolumn{3}{|c|}{ Strip } \\
\hline & $1 \mathrm{AF}$ & $1 \mathrm{AS}$ & $1 \mathrm{AA}$ & $1 \mathrm{AX} \mathrm{X}^{\mathrm{a}}$ & $1 \mathrm{AP}^{\mathrm{a}}$ & $1 \mathrm{AW}$ & $1 \mathrm{BXF}^{\mathrm{a}}$ & $1 \mathrm{BX}$ & $1 \mathrm{BU}^{\mathrm{a}}$ & $1 \mathrm{BXT}$ & \multirow{2}{*}{$\frac{1 \mathrm{BS}^{\mathrm{a}}}{\mathrm{In}}$} & $1 \mathrm{BT}$ & $1 \mathrm{BSU}{ }^{\mathrm{a}}$ & \multirow{2}{*}{$\frac{1 \mathrm{CX}}{\mathrm{In}}$} & $1 \mathrm{CU}$ & $1 \mathrm{CW}^{\mathrm{a}}$ \\
\hline & \multicolumn{4}{|c|}{ In } & \multicolumn{2}{|c|}{ Out } & \multicolumn{2}{|c|}{ In } & \multicolumn{2}{|c|}{ Out } & & \multicolumn{2}{|c|}{ out } & & \multicolumn{2}{|c|}{ Out } \\
\hline Flow, $\mathrm{ml} / \mathrm{min}$ & 12 & 20 & 2.5 & 120 & 120 & 34 & 155 & 109 & 155 & 109 & 35 & 109 & 35 & 28 & 28 & 155 \\
\hline $\mathrm{U}, \mathrm{kg} / \mathrm{m}^{3}$ & 12 & & & & 1.2 & b & 1.0 & & 0.9 & 0.13 & & $\mathrm{~b}$ & 0.42 & & 5.2 & $\mathrm{~b}$ \\
\hline $\mathrm{Th}, \mathrm{kg} / \mathrm{m}^{3}$ & 348 & & & & 34.8 & 0.04 & 31.1 & & $\mathrm{~b}$ & 44.3 & & 38.5 & 18.2 & & & $\mathrm{~b}$ \\
\hline FPs, $\mathrm{kg} / \mathrm{m}^{3}$ & 17 & & & & $\mathrm{~b}$ & 5.9 & $\mathrm{~b}$ & & b & $\mathrm{b}$ & & $\mathrm{b}$ & b & & $\mathrm{b}$ & \\
\hline $\mathrm{HNO}_{3}, \mathrm{kmol} / \mathrm{m}^{3}$ & 1.0 & 1.0 & 13 & 20.01 & 0.13 & 1.4 & 0.11 & 0.2 & 0.018 & 0.33 & 20.01 & 0.32 & 0.05 & 0.01 & 0.11 & $<0.01$ \\
\hline
\end{tabular}

$\mathrm{a}_{30 \text { vol } \% \text { TBP-70\% NPH. }}$

Trace. 
The quantity of irradiated fuel avallable for this inftial series of tests was limited, constraining the scale of these experiments. Therefore, each experiment was designed for batch extractions performed in sequential stages. These batch extractions do not correspond to stages in a column. However, the resulting concentrations provide distribution data in the general concentration ranges expected in the process equipment. The distribution data were used to locate the equilibrium line in a McCabe-Thiele column analysis.

The tests were performed in the laboratory with standardized, synthetic solutions containing nonradioactive ("cold") constituents and also in the hot cell using a feed prepared by dissolving irradiated ("hot") High-Temperature Gas-Cooled Reactor (HTGR) fuel obtained from the Peach Bottom Reactor. The whole series of tests with irradiated fuel were continued to completion without awaiting analytical results to avold problems resulting from radiation damage to the test solutions. The experimental results were subjected to the following tests to determine their internal consistency before broadening any interpretation of the results: (1) material balances for volume, $\mathrm{HNO}_{3}$, uranium, and thorium; and (2) comparison with the SEPHIS-MOD4 calculations.

Material balances compare inputs with outputs and are widely used as a first screening of experimental results. The degree of closing of the material balances (approaching $100 \%$ as an idea1) indicates how closely the experiment was controlled for the amounts and concentrations of the inputs and outputs of materials. Where the material balances are poor, one may be able to differentiate between possible causes of poor material balances by comparisons between the results of the four balances struck in this experiment. Such comparisons are made throughout this report.

The second test of internal consistency is based on the comparison between the experimental results and the calculations made using the SEPHIS-MOD code. 1 The SEPHIS-MOD4 program is a computer simulation of solvent extraction processes. (The correlations for the Thorex distribution coefficients were developed by $S$. B. Watson and $R$. H. Rainey. ${ }^{2}$ Third-phase data were produced by A. J. Weinberger et al. ${ }^{3}$ ). 
The SEPHIS-MOD4 always calculates good material balances, but one is not yet sure that the distribution relationships are sufficiently general for unquestioning use of the code. (One goal for these hotcell studies is the verification of the SEPHIS-MOD4 THOREX code by obtaining good agreement between calculation and experiment.)

The SEPHIS-MOD4 was used to set up the conditions for our first tests of the "hot" extraction system, and after the tests, to mode 1 the actual behavior. Comparisons of experimental results with SEPHIS-MOD4 predictions are also made throughout this report. Where calculations from the SEPHIS-MOD4 program are compared with experimental results, the calculations are for batch operations using the analytically determined concentrations for the various feed solutions.

The discussion in this report will generally be limited to the behavior of thorium and nitric acid, because problems with the analysis of uranium at the time these tests were made largely precluded interpretation of the uranium results. Since these experiments were completed, improvements have been made in the analysis for uranium. However, continued development of new or improved analytical procedures is desirable for highly radioactive solutions.

We have sought to maximize the amount of information one can obtain from this work by using the SEPHIS-MOD4 program to assist in the interpretation of the data. The test data are divided into three sets: (1) where the flowsheet parameters appear to be correctly specified, (2) where the flowsheet parameters appear to be incorrectly specified, and (3) where the test results are inconclusive due to experimental or analytical uncertainties. These sets are discussed in Sect. 6 .

\section{EQUIPMENT}

Two sets of extraction equipment were employed in the experiments to provide duplicate results for each contact. Cylindrical 250-m1 glass separatory funnels were used for the extractions. Perforated shaft stirrers attached to synchronized, controlled speed motors were used to mix the solutions. Scouting trials indicated that a $2-m i n$ extraction time with a motor speed of $2000 \mathrm{rpm}$ provided satisfactory contact with this equipment. 
Following the cold laboratory tests, the assemblies were dismantled, placed in the hot cell, and reassembled for the tests with radioactive solutions.

\section{SOLUTIONS}

A synthetic feed solution was prepared for the cold tests to simulate a solution of dissolved, radioactive, HTGR fuel. Depleted uranyl nitrate and thorium nitrate were used to provide the heavy-metal concentrations. Twenty-nine nonradioactive nuclides of the elements predicted by the ORNL Isotope Generation and Depletion Code (ORIGEN, a computer program used for predicting quantities of activation products, actinides, and fission products from irradiation data and nuclear data libraries) ${ }^{4}$ were included in the solution. The analytical results are listed in Table 2 along with the criteria established by the flowsheet. The uranium and thorium concentrations were analyzed to be within 2 and $5 \%$, respectively. The acid concentration was considerably higher than the criterion specified (i.e., $2.8 \mathrm{kmol} / \mathrm{m}^{3}$ vs $1.0 \mathrm{kmol} / \mathrm{m}^{3}$ ). However, since batch extractions were used in the experiments, the acid concentration was adjusted for each use by regulating the amount of $\mathrm{HNO}_{3}$ added to represent the scrub or strip solutions. In true countercurrent operation, the nitric acid will reflux in the extraction part of the column, but this was not simulated in these experiments.

The solvent was prepared from virgin tributylphosphate (TBP) and virgin normal paraffinic hydrocarbon (NPH). Samples of the solution were analyzed and reported to be $31.4 \% \mathrm{TBP} / \mathrm{NPH},<0.01 \mathrm{kmol} / \mathrm{m}^{3} \mathrm{HNO}_{3}$ $\approx$ mol $/ \mathrm{m}^{3}$ dibutylphosphate, with a density of $823.5 \mathrm{~kg} / \mathrm{m}^{3}$.

A quantity of irradiated fuel was crushed, burned, and dissolved by C. L. Fitzgerald as a part of the head-end study ${ }^{5}$ in the HTGR fuel reprocessing program. The solution was evaporated to remove the bulk of the nitric acid. It was then diluted to adjust the remaining components, especially the heavy metals, to flowsheet specification.

\section{EXPER IMENTAL}

The four major flowsheet conditions were studied - extraction, partition, partition-scrub, and strip operation. Each condition was tested with the simulated feed solution and the radioactive feed solution. 
Table 2. Feed (IAF) criteria/composition

\begin{tabular}{lcc}
\hline Component & Criterion & $\begin{array}{c}\text { Synthetic concentration } \\
\text { (by analysis) }\end{array}$ \\
\hline $\mathrm{U}, \mathrm{kg} / \mathrm{m}^{3}$ & 12 & 11.8 \\
$\mathrm{Th}, \mathrm{kg} / \mathrm{m}^{3}$ & 348 & 331 \\
Fission products, $\mathrm{kg} / \mathrm{m}^{3}$ & 17 & $19.2^{\mathrm{a}}$ \\
$\mathrm{Cd}, \mathrm{kg} / \mathrm{m}^{3}$ & 7.5 & 7.5 \\
$\mathrm{~A} 1, \mathrm{~kg} / \mathrm{m}^{3}$ & 3.8 & 3.5 \\
$\mathrm{~F}^{-}, \mathrm{kmol} / \mathrm{m}^{3}$ & 0.07 & 0.04 \\
$\mathrm{HNO}{ }_{3}, \mathrm{kmol} / \mathrm{m}^{3}$ & 1.00 & 2.78 \\
\hline
\end{tabular}

${ }^{a}$ Nonradioactive species. 


\subsection{Extraction Column}

The extraction operation (the $1 \mathrm{~A}$ column) is designed to transfer the uranium and thorium into the organic phase while leaving the fission products in the aqueous phase. The experiment was made with consecutive, crosscurrent batch extractions using a ratio of one volume of adjusted feed solution to contact approximately 3.5 volumes of $30 \% \mathrm{TBP}$ in an NPH diluent. The coextraction of thorium and uranium was studied in experiment 12 with synthetic feed and again in experiment 13 using radioactive feed.

A schematic diagram representing experiment 12 is shown in Fig. 2. Following each contact, the phases were separated, and sma11 samples in duplicate were removed from each solution (as $1 \mathrm{AP}-1,1 \mathrm{~A}$, $1 \mathrm{AW}-1,1 \mathrm{~A}$, etc.). The remaining aqueous volume was contacted with a constant volume of fresh $30 \% \mathrm{TBP} / \mathrm{NPH}$ solution (1AX) and a concentrated acid solution (IAA) in each of the eight successive extractions. As a result, the organic-to-aqueous ratio progressively increased throughout the experiment.

It should be noted that the $1 \mathrm{AA}$ additions do not exactly correspond to the IAA stream in Fig. 1. With an actual column the IAA stream is used primarily to acidify the incoming organic stream. With these batch extractions multiple portions of $1 \mathrm{AA}$ must be used since the aqueous solution is being contacted with a fresh organic solution rather than an acidified organic solution. Without the multiple additions of 1AA, the acid in the aqueous phase would be quickly depleted by the contacts with the organic phase. (The procedure was modified in experiment 13 to hold the organic-to-aqueous phase ratio constant by using a volume of solvent in each extraction that was proportional to the remaining volume of aqueous solution.)

The material balances for experiment 12 based on the chemical analyses for nitric acid, uranium, and thorium are shown in Table 3. The acid recovery ranged from $102 \%$ in stage 5 to $133 \%$ in stage 1 . The average was $109 \%$. The thorium recovery was between 75 and $229 \%$, with an average of $137 \%$. 


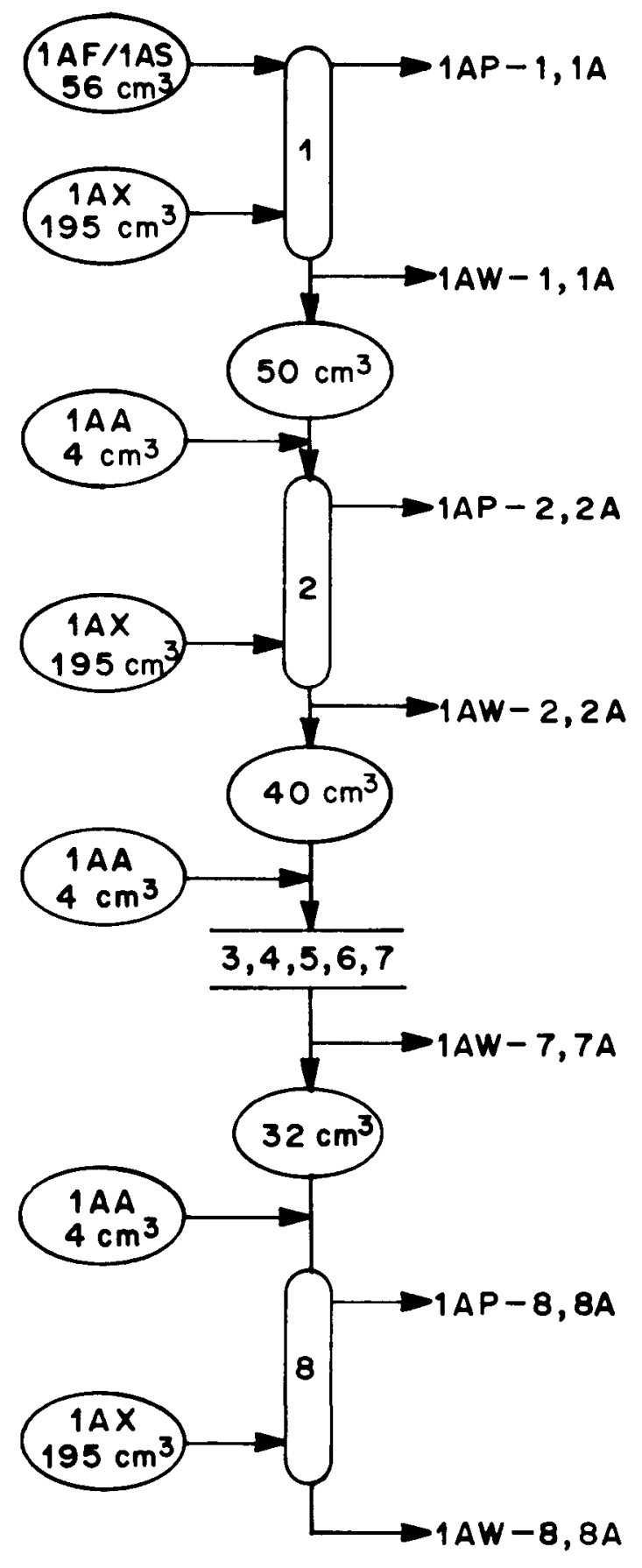

$$
\text { 1AF/1AS } \begin{aligned}
& 4.09 \mathrm{~kg} / \mathrm{m}^{3} \mathrm{U} \\
& 115.3 \mathrm{~kg} / \mathrm{m}^{3} \mathrm{Th} \\
& 1.9 \mathrm{kmol} / \mathrm{m}^{3} \mathrm{HNO}_{3} \\
\text { 1AX } & 30 \% \mathrm{TBP} / 70 \% \mathrm{NDD} \\
\text { 1AA } & 13 \mathrm{kmol} / \mathrm{m}^{3} \mathrm{HNO}_{3}
\end{aligned}
$$

Fig. 2. Schematic diagram of the cold extraction test, experiment 12, IA column. 
Table 3. Material balances for the cold extraction test, experiment 12, 1A column

\begin{tabular}{|c|c|c|c|c|c|c|c|c|c|}
\hline \multirow[b]{2}{*}{$\mathrm{CR}-5$} & \multicolumn{2}{|c|}{$\begin{array}{c}\text { Acid } \\
\text { (mmol) }\end{array}$} & \multirow[b]{2}{*}{ recovery } & \multicolumn{2}{|c|}{$\begin{array}{c}\text { Uranium } \\
\text { (mg) }\end{array}$} & \multirow[b]{2}{*}{ recovery } & \multicolumn{2}{|c|}{$\begin{array}{c}\text { Thorium } \\
\text { (mg) }\end{array}$} & \multirow[b]{2}{*}{$\%$ recovery } \\
\hline & In & Out & & In & Out & & In & Out & \\
\hline $\begin{array}{l}1 \mathrm{AF} / 1 \mathrm{AS} \\
1 \mathrm{AP}-1^{\mathrm{a}} \\
1 \mathrm{AW}-1^{\mathrm{b}}\end{array}$ & 106.2 & $\begin{array}{l}49.7 \\
91.8\end{array}$ & 133 & 229.4 & $\begin{array}{r}95.5 \\
1.6\end{array}$ & 42.3 & 6455 & $\begin{array}{l}3744 \\
1112\end{array}$ & 75.2 \\
\hline $\begin{array}{l}1 \mathrm{AW}-1 \\
1 \mathrm{AP}-2 \\
1 \mathrm{AW}-2\end{array}$ & 134.8 & $\begin{array}{l}67.3 \\
75.6\end{array}$ & 106 & 1.42 & $\begin{array}{l}3.47 \\
0.66\end{array}$ & 291 & 993 & $\begin{array}{r}1112 \\
246\end{array}$ & 137 \\
\hline $\begin{array}{l}1 \mathrm{AW}-2 \\
1 \mathrm{AP}-3 \\
1 \mathrm{AW}-3\end{array}$ & 108.0 & $\begin{array}{l}62.4 \\
53.9\end{array}$ & 108 & 0.49 & $\begin{array}{l}0.82 \\
0.12\end{array}$ & 192 & 182 & $\begin{array}{r}201 \\
34\end{array}$ & 129 \\
\hline $\begin{array}{l}1 \mathrm{AW}-3 \\
1 \mathrm{AP}-4 \\
1 \mathrm{AW}-4\end{array}$ & 101.2 & $\begin{array}{l}56.6 \\
51.3\end{array}$ & 107 & 0.11 & $\begin{array}{l}0.23 \\
0.29\end{array}$ & 473 & 31.1 & $\begin{array}{r}26.0 \\
7.0\end{array}$ & 106 \\
\hline $\begin{array}{l}1 \mathrm{AW}-4 \\
1 \mathrm{AP}-5 \\
1 \mathrm{AW}-5\end{array}$ & 98.6 & $\begin{array}{l}52.6 \\
47.5\end{array}$ & 102 & 0.26 & $\begin{array}{l}0.66 \\
0.11\end{array}$ & 296 & 6.4 & $\begin{array}{l}5.9 \\
2.6\end{array}$ & 132 \\
\hline $\begin{array}{l}1 \mathrm{AW}-5 \\
1 \mathrm{AP}-6 \\
1 \mathrm{AW}-6\end{array}$ & 89.8 & $\begin{array}{l}53.6 \\
43.7\end{array}$ & 108 & 0.08 & $\begin{array}{l}0.60 \\
0.13\end{array}$ & 913 & 2.0 & $\begin{array}{l}1.8 \\
1.3\end{array}$ & 155 \\
\hline $\begin{array}{l}1 \mathrm{AW}-6 \\
1 \mathrm{AP}-7 \\
1 \mathrm{AW}-7\end{array}$ & 91.2 & $\begin{array}{l}54.6 \\
41.3\end{array}$ & 105 & 0.12 & $\begin{array}{l}0.55 \\
0.13\end{array}$ & 567 & 1.2 & $\begin{array}{l}0.7 \\
0.9\end{array}$ & 133 \\
\hline $\begin{array}{l}1 \mathrm{AW}-7 \\
1 \mathrm{AP}-8 \\
1 \mathrm{AW}-8\end{array}$ & 85.9 & $\begin{array}{l}51.7 \\
37.3\end{array}$ & 104 & 0.11 & $\begin{array}{l}0.20 \\
0.04\end{array}$ & 218 & 0.7 & $\begin{array}{l}1.0 \\
0.6\end{array}$ & 229 \\
\hline
\end{tabular}


The results from the chemical analysis of the samples taken during experiment 12 are listed in Table 4, along with the values predicted by the SEPHIS-MOD4 program. In general, the free acid values compare favorably. However, a slight bias is evident in the results that reflect the higher experimental recoveries $(109 \%)$. The agreement improved in the final contacts.

About $94 \%$ of the uranium present in the initial feed solution was extracted in the first two stages. The uranium remaining in the aqueous phase after the first two stages was generally too low in concentration for a reliable measurement by the analytical technique used.

There was qualitative agreement between the analytical thorium results and the SEPHIS-MOD4 predictions. However, the analytical values for thorium in the first five stages were lower than the corresponding SEPHIS values, indicating better extraction than predicted. This may be the consequence of the low (75\%) thorium recovery in the first stage and the higher aqueous acidities in the first few stages.

The distribution coefficients, $\mathrm{E}_{\mathrm{A}}^{\mathrm{O}}$, calculated from the analytical results compare favorably with those calculated by the SEPHIS-MOD4 program (Table 5). The higher experimental values for uranium and thorium in the first few stages are probably the result of the higher acid concentrations. It should be noted that the SEPHIS-MOD4 program calculates ideal mass balances.

A schematic diagram representing experiment 13 is shown in Fig. 3. The acidity of the dissolved radioactive fuel was adjusted to that of the IAF/IAS combined stream by adding dilute nitric acid.

The experiment was conducted in ten sequential extraction stages. Each stage consisted of duplicate extractions to provide a check on the experimental performance. After mixing, the solutions were allowed to stand undisturbed to achieve phase separation. In each of the first five extractions, the aqueous layer was drained from the extraction vessel along with 1 to $3 \mathrm{ml}$ of the organic layer to ensure maxiumum recovery of the aqueous phase for subsequent tests. This resulted in an undesirable back-mixing effect. In the sixth and subsequent stages, an improved operating technique achieved aqueous-phase removal without significant organic back-mixing. The aqueous raffinates 
Table 4. Comparison of analytical values with SEPHIS ${ }^{\text {a }}$ predictions for cold extraction test, experiment 12 , lA column

\begin{tabular}{|c|c|c|c|c|c|c|}
\hline \multirow[b]{2}{*}{ Sample } & \multicolumn{2}{|c|}{$\mathrm{H}^{+}\left(\mathrm{kmol} / \mathrm{m}^{3}\right)$} & \multicolumn{2}{|c|}{$\mathrm{U}\left(\mathrm{kg} / \mathrm{m}^{3}\right)$} & \multicolumn{2}{|c|}{ Th $\left(\mathrm{kg} / \mathrm{m}^{3}\right)$} \\
\hline & Analysis & SEPHIS & Analysis & SEPHIS & Analysis & SEPHIS \\
\hline $\begin{array}{l}1 \mathrm{AP}-1 \mathrm{~b} \\
1 \mathrm{AW}-1\end{array}$ & $\begin{array}{l}0.26 \\
1.64\end{array}$ & $\begin{array}{l}0.21 \\
1.20\end{array}$ & $\begin{array}{l}0.490 \\
0.0284\end{array}$ & $\begin{array}{l}1.14 \\
0.129\end{array}$ & $\begin{array}{l}19.2 \\
19.9\end{array}$ & $\begin{array}{l}23.5 \\
33.5\end{array}$ \\
\hline $\begin{array}{l}1 \mathrm{AP}-2 \\
1 \mathrm{AW}-2\end{array}$ & $\begin{array}{l}0.35 \\
1.40\end{array}$ & $\begin{array}{l}0.26 \\
1.14\end{array}$ & $\begin{array}{l}0.018 \\
0.012\end{array}$ & $\begin{array}{l}0.032 \\
0.0029\end{array}$ & $\begin{array}{l}5.70 \\
4.55\end{array}$ & $\begin{array}{l}6.29 \\
8.30\end{array}$ \\
\hline $\begin{array}{l}1 \mathrm{AP}-3 \\
1 \mathrm{AW}-3\end{array}$ & $\begin{array}{l}0.32 \\
1.23\end{array}$ & $\begin{array}{l}0.26 \\
1.08\end{array}$ & $\begin{array}{l}0.0042 \\
0.0028\end{array}$ & $\begin{array}{r}0.0006 \\
<0.0001\end{array}$ & $\begin{array}{l}1.03 \\
0.780\end{array}$ & $\begin{array}{l}1.26 \\
1.97\end{array}$ \\
\hline $\begin{array}{l}1 \mathrm{AP}-4 \\
1 \mathrm{AW}-4\end{array}$ & $\begin{array}{l}0.29 \\
1.17\end{array}$ & $\begin{array}{l}0.26 \\
1.04\end{array}$ & $\begin{array}{l}0.0012 \\
0.0065\end{array}$ & $\begin{array}{l}<0.0001 \\
<0.0001\end{array}$ & $\begin{array}{l}0.134 \\
0.159\end{array}$ & $\begin{array}{l}0.291 \\
0.502\end{array}$ \\
\hline $\begin{array}{l}1 \mathrm{AP}-5 \\
1 \mathrm{AW}-5\end{array}$ & $\begin{array}{l}0.27 \\
1.08\end{array}$ & $\begin{array}{l}0.25 \\
1.03\end{array}$ & $\begin{array}{l}0.0034 \\
0.0024\end{array}$ & $\begin{array}{l}<0.0001 \\
<0.0001\end{array}$ & $\begin{array}{l}0.031 \\
0.058\end{array}$ & $\begin{array}{l}0.073 \\
0.132\end{array}$ \\
\hline $\begin{array}{l}1 \mathrm{AP}-6 \\
1 \mathrm{AW}-6\end{array}$ & $\begin{array}{l}0.28 \\
1.12\end{array}$ & $\begin{array}{l}0.25 \\
1.03\end{array}$ & $\begin{array}{l}0.0031 \\
0.0033\end{array}$ & & $\begin{array}{l}0.009 \\
0.034\end{array}$ & $\begin{array}{l}0.017 \\
0.032\end{array}$ \\
\hline $\begin{array}{l}1 \mathrm{AP}-7 \\
1 \mathrm{AW}-7\end{array}$ & $\begin{array}{l}0.28 \\
1.06\end{array}$ & $\begin{array}{l}0.25 \\
1.02\end{array}$ & $\begin{array}{l}0.0028 \\
0.0033\end{array}$ & & $\begin{array}{l}0.004 \\
0.023\end{array}$ & $\begin{array}{l}0.004 \\
0.008\end{array}$ \\
\hline $\begin{array}{l}1 \mathrm{AP}-8 \\
1 \mathrm{AW}-8\end{array}$ & $\begin{array}{l}0.27 \\
1.04\end{array}$ & $\begin{array}{l}0.25 \\
1.02\end{array}$ & $\begin{array}{l}0.0011 \\
0.0012\end{array}$ & & $\begin{array}{l}0.005 \\
0.017\end{array}$ & $\begin{array}{l}0.001 \\
0.002\end{array}$ \\
\hline
\end{tabular}

${ }^{a}$ SEPHIS predictions at $30^{\circ} \mathrm{C}$.

borganic phase.

${ }^{c}$ Aqueous phase. 
Table 5. Distribution coefficients for cold extraction test, experiment $12,1 \mathrm{~A}$ column

\begin{tabular}{|c|c|c|c|c|c|c|}
\hline \multirow{2}{*}{$\begin{array}{c}\text { Extraction } \\
\text { No. }\end{array}$} & \multicolumn{2}{|c|}{$\mathrm{H}^{+}, \mathrm{E}_{\mathrm{A}}^{\mathrm{O}}$} & \multicolumn{2}{|c|}{$\mathrm{U}, \mathrm{E}_{\mathrm{A}}^{\mathrm{O}}$} & \multicolumn{2}{|c|}{$\mathrm{Th}, \mathrm{E}_{\mathrm{A}}^{\mathrm{o}}$} \\
\hline & Analysis & $\overline{\text { SEPHIS }}$ & Analysis & $\overline{\text { SEPHIS }}$ & Analysis & $\overline{\text { SEPHIS }}$ \\
\hline 1 & 0.16 & 0.18 & 17.3 & 8.9 & 1.0 & 0.7 \\
\hline 2 & 0.25 & 0.23 & 1.5 & 11.1 & 1.3 & 0.8 \\
\hline 3 & 0.26 & 0.24 & 1.5 & - & 1.3 & 0.6 \\
\hline 4 & 0.25 & 0.25 & 0.2 & - & 0.8 & 0.6 \\
\hline 5 & 0.25 & 0.24 & 1.4 & - & 0.5 & 0.6 \\
\hline 6 & 0.25 & 0.24 & 0.9 & - & 0.3 & 0.5 \\
\hline 7 & 0.26 & 0.25 & 0.9 & - & 0.2 & 0.5 \\
\hline 8 & 0.26 & 0.25 & 0.9 & - & 0.3 & 0.5 \\
\hline
\end{tabular}




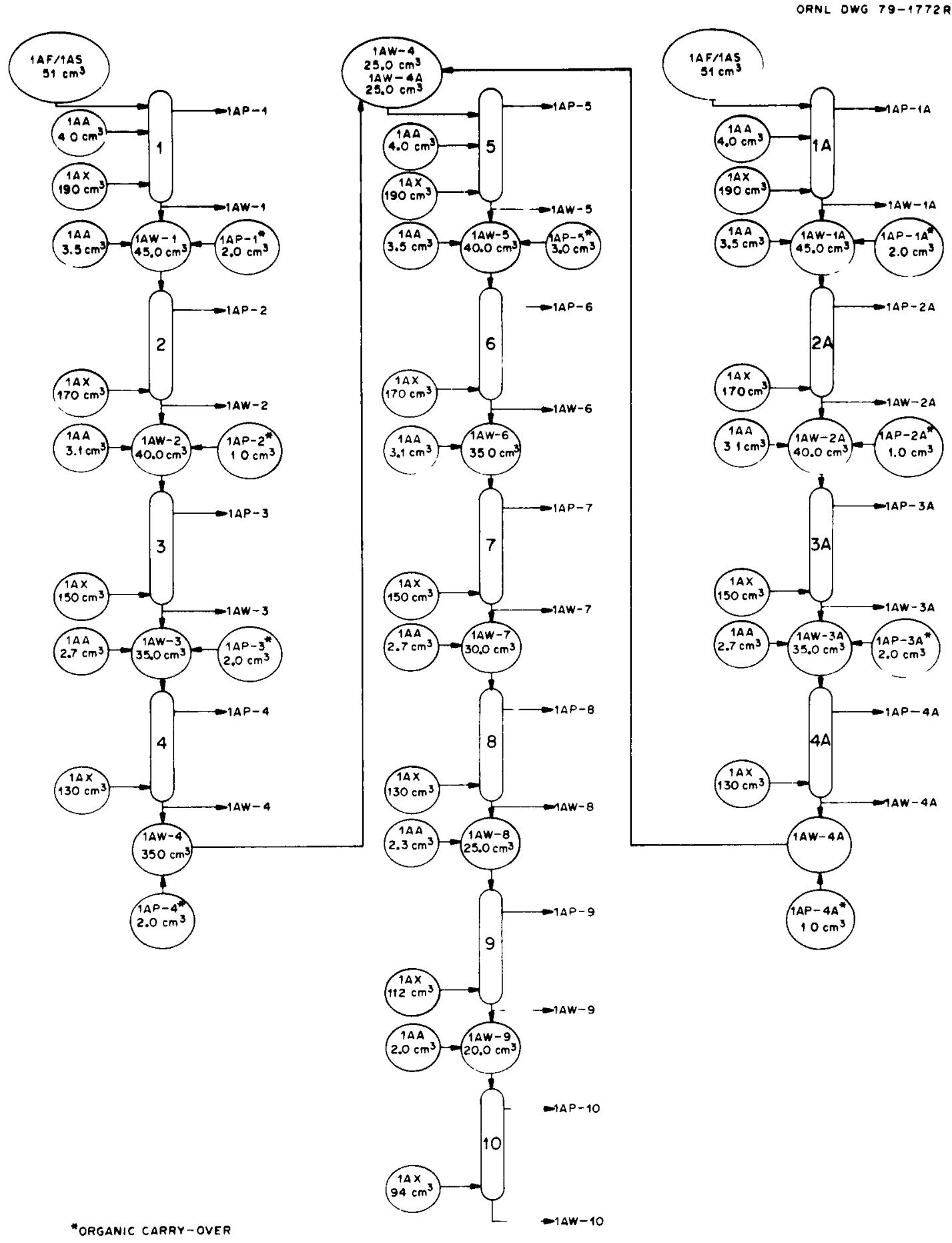

SCHEMATIC DIAGRAM OF THE HOT EXTRACTION TEST, EXPERIMENT NO 13, 1A COLUMN

Fig. 3. Schematic diagram of the hot extraction test, experiment 13, $1 \mathrm{~A}$ column. 
from the two fourth-stage extractions were combined to provide enough solution to continue the study for six additional stages.

The results of experiment 13 are listed in Table 6. As in experiment 12 , the free acid values by analysis were in good agreement with SEPHIS-MOD4 predictions. The organic samples showed excellent agreement after the first stage.

The thorium results by analysis compared reasonably well with the SEPHIS-MOD4 predictions. However, the agreement decreased as the experiment proceeded. This could be due to accumulating errors between the experiment and the SEPHIS inputs. In addition, there is an apparent disparity between the analytical values of the duplicate samples from the aqueous phase (1AW) in stages $3(134 \%)$ and $4(100 \%)$.

These first experimental results of the hot-cell Thorex flowsheet tests are "noisy;" however, one may still obtain useful information from them. Using a MaCabe-Thiele diagram, one may estimate how well the extraction column would work. McCabe-Thiele diagrams of the thorium behavior in the cold and hot experiments are shown in Figs. 4 and 5 respectively. The operating line in each diagram is the material balance line and is determined by the flow ratio in the extraction section. The stepped line represents the number of theoretical stages required to achieve a certain degree of extraction. In Fig. 4, the duplicate values for the thorium extractions are reasonably close. In Fig. 5, the replicates at the lower concentrations split into two groups. The more conservative values were chosen for the stage analysis. With both of these samples, the extraction seems to be possible with the given operating conditions for the $1 \mathrm{~A}$ column.

It is important to note that in true countercurrent operation, the nitric acid will reflux in the extraction section of the column. This reflux was not properly simulated in the experiments. In practice, the resulting higher acidity should make the extraction of thorium even more favorable. Another test with irradiated fuel and higher acidities should be made to simulate this acid reflux and to test the behavior of the uranium in the irradiated system. 
Table 6. Comparison of analytical values with SEPHIS ${ }^{\text {a }}$ predictions for hot extraction test, experiment 13, 1A column

\begin{tabular}{|c|c|c|c|c|c|c|}
\hline \multirow[b]{2}{*}{ Sample } & \multicolumn{2}{|c|}{$\mathrm{H}^{+}\left(\mathrm{kmol} / \mathrm{m}^{3}\right)$} & \multicolumn{2}{|c|}{$\mathrm{U}\left(\mathrm{kg} / \mathrm{m}^{3}\right)$} & \multicolumn{2}{|c|}{$\mathrm{Th}\left(\mathrm{kg} / \mathrm{m}^{3}\right)$} \\
\hline & Analysis & SEPHIS & Analysisb & $\overline{\text { SEPHIS }}$ & Analysis & SEPHIS \\
\hline $\begin{array}{l}1 \mathrm{AP}-1^{\mathrm{b}} \\
1 \mathrm{AP}-1 \mathrm{~A}\end{array}$ & $\begin{array}{l}0.25 \\
0.25\end{array}$ & 0.20 & $\begin{array}{l}0.539 \\
0.437\end{array}$ & 2.76 & $\begin{array}{l}23.9 \\
25.3\end{array}$ & 24.4 \\
\hline $1 \mathrm{AW}-1_{\mathrm{C}}^{\mathrm{d}}$ & 1.32 & & 0.058 & & 30.2 & \\
\hline $1 \mathrm{AW}-1 \mathrm{~A}$ & 1.37 & 1.24 & 0.705 & 0.364 & 33.8 & 37.0 \\
\hline $1 \mathrm{AP}-2 \mathrm{c}$ & 0.26 & & 0.033 & & 6.70 & \\
\hline $1 \mathrm{AP}-2 \mathrm{~A}$ & 0.27 & 0.27 & 0.028 & 0.124 & 6.56 & 7.28 \\
\hline $1 \mathrm{AW}-2 \mathrm{c}$ & 1.32 & & 0.089 & & 8.66 & \\
\hline $1 A W-2 A$ & 1.42 & 1.16 & 0.076 & 0.011 & 9.07 & 9.55 \\
\hline $1 \mathrm{AP}-3 \mathrm{C}$ & 0.26 & & 0.0032 & & 1.66 & \\
\hline $1 \mathrm{AP}-3 \mathrm{~A}$ & 0.27 & 0.27 & 0.0044 & 0.0037 & 1.67 & 1.79 \\
\hline $1 \mathrm{AW}-3 \mathrm{c}$ & 1.32 & & 0.021 & & 3.29 & \\
\hline $1 \mathrm{AW}-3 \mathrm{~A}$ & 1.37 & 1.09 & 0.043 & 0.0004 & 0.650 & 2.75 \\
\hline $1 \mathrm{AP}-4 \mathrm{c}$ & 0.26 & & 0.0027 & & 0.494 & \\
\hline $1 \mathrm{AP}-4 \mathrm{~A}^{\mathrm{C}}$ & 0.27 & 0.26 & 0.0008 & 0.0002 & 0.620 & 0.508 \\
\hline $1 \mathrm{AW}-4 \mathrm{c}$ & 1.27 & & 0.0012 & & 1.29 & \\
\hline $1 \mathrm{AW}-4 \mathrm{~A}$ & 1.37 & 1.05 & 0.0026 & $<0.0001$ & 0.430 & 0.871 \\
\hline $1 \mathrm{AP}-5$ & 0.26 & 0.26 & 0.0070 & $<0.0001$ & 0.119 & 0.156 \\
\hline $1 \mathrm{AW}-5$ & 1.27 & 1.04 & 0.0014 & $<0.0001$ & 0.550 & 0.278 \\
\hline $1 \mathrm{AP}-6$ & 0.26 & 0.26 & 0.0007 & & 0.192 & 0.046 \\
\hline $1 \mathrm{AW}-6$ & 1.32 & 1.02 & $0 . n 026$ & & 0.230 & 0.085 \\
\hline $1 \mathrm{AP}-7$ & 0.26 & 0.25 & 0.0041 & & 0.055 & 0.134 \\
\hline $1 \mathrm{AW}-7$ & 1.27 & 1.02 & 0.0029 & & 0.074 & 0.025 \\
\hline $1 \mathrm{AP}-8$ & 0.26 & 0.25 & 0.0012 & & 0.017 & 0.004 \\
\hline $1 \mathrm{AW}-8$ & 1.32 & 1.02 & 0.0013 & & 0.054 & 0.008 \\
\hline $1 \mathrm{AP}-9$ & 0.26 & 0.25 & 0.0015 & & 0.020 & 0.001 \\
\hline $1 \mathrm{AW}-9$ & 1.27 & 1.01 & 0.0012 & & 0.038 & 0.002 \\
\hline $1 \mathrm{AP}-10$ & 0.26 & 0.26 & 0.0017 & & 0.008 & $<0.001$ \\
\hline $1 \mathrm{AW}-10$ & 1.27 & 1.03 & 0.0021 & & 0.011 & $<0.001$ \\
\hline
\end{tabular}

\footnotetext{
${ }^{a}$ SEPHIS predictions at $32^{\circ} \mathrm{C}$.

organic phase.

Experimental results from a duplicate run.

dqueous phase.
} 


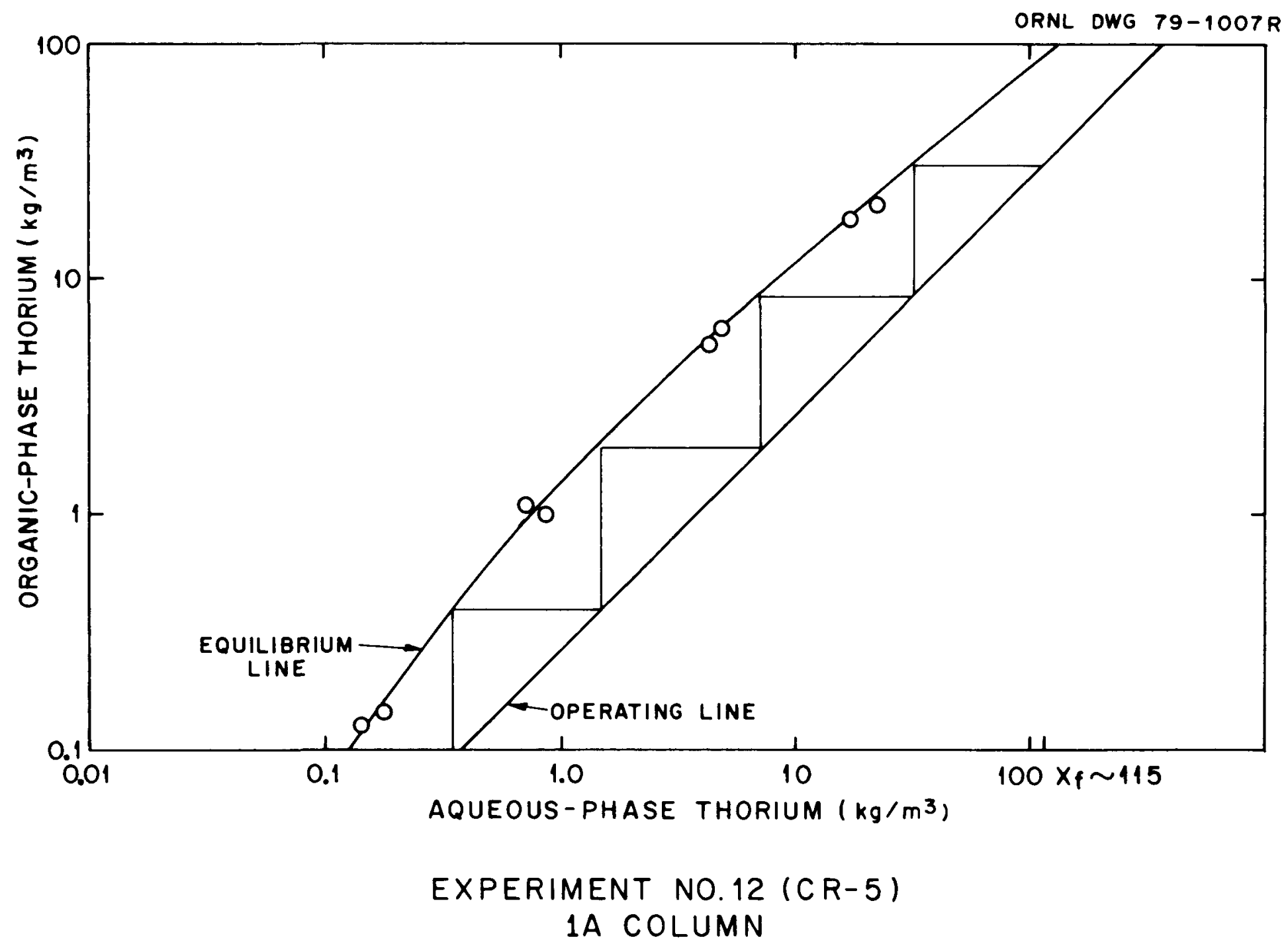

Fig. 4. McCabe-Thiele diagram for cold extraction test, experiment 12, 1A column. 


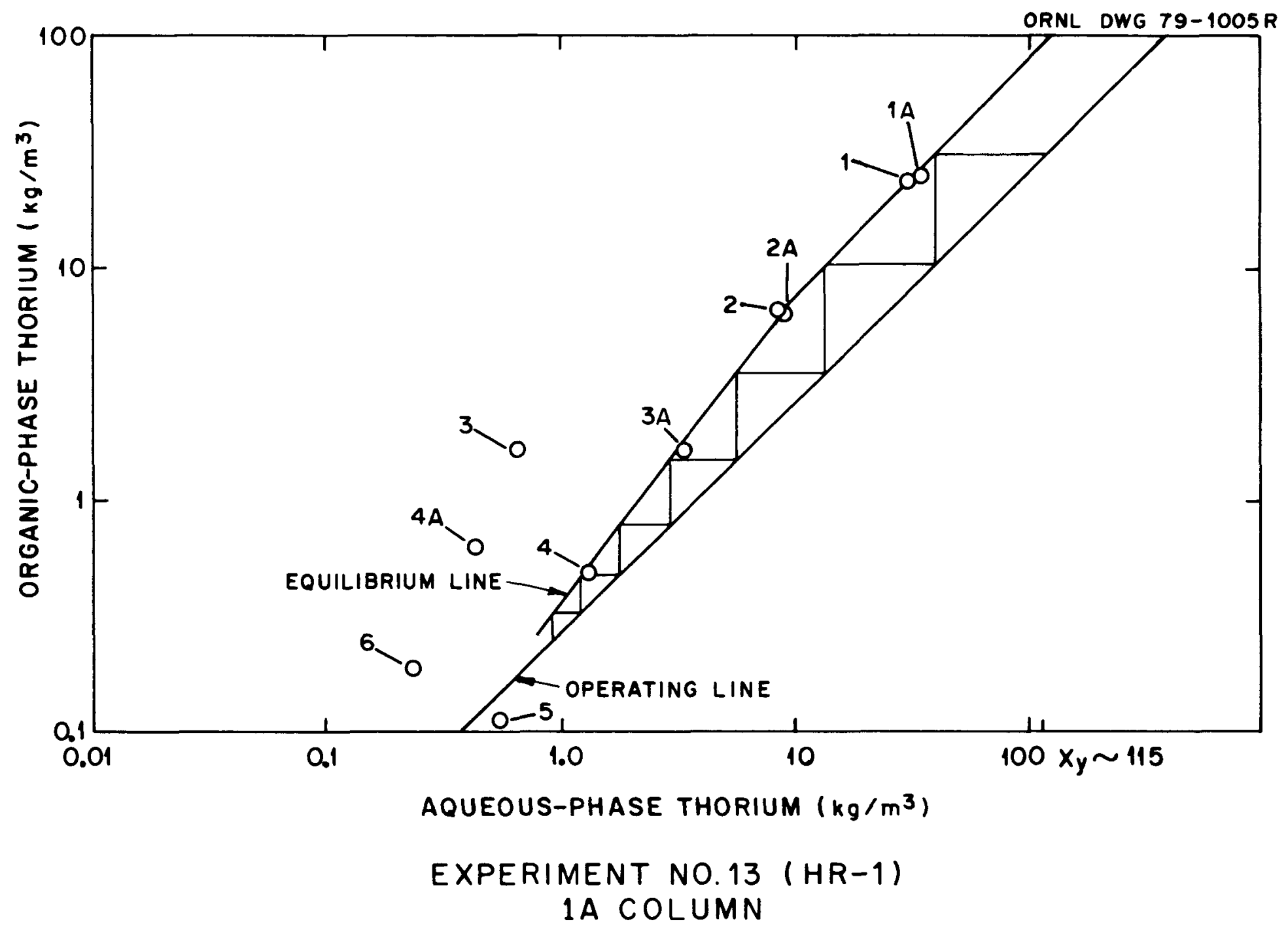

Fig. 5. McCabe-Thiele diagram for hot extraction test, experiment 13, 1A column. Data points are identified by contact numbers (see Fig. 3). 


\subsection{Partition Column}

The partitioning of the thorium and uranium in the $1 B X$ column was also simulated with both cold and hot experiments. The partition column was designed to transfer the thorium from the organic to the aqueous phase with minimal uranium stripping. Its effectiveness was tested with both a cold synthetic solution and a solution containing radioactive components. For the cold test, experiment 4, a volume of $30 \%$ TBP-NPH solution, was impregnated with uranyl nitrate and thorium nitrate to simulate the 1BXF stream (Table 1). This solution was used in the partitioning experiment two days later. In the hot test, experiment 14, the first IAP solution removed from experiment 13 (Fig. 3) a week earlier, was used as the $1 B X F$. In each of the experiments, six sequential contacts were made between the $1 \mathrm{BXF}$ solution and 0.2 $\mathrm{kmol} / \mathrm{m}^{3} \mathrm{HNO}_{3}$ (1BX) solutions.

The data resulting from the cold and hot experiments are shown in Tables 7 and 8 respectively. In all but the first stage of the hot experiment (Table 8 ), the analytical results showed the nitric acid concentrations to be $<0.2 \mathrm{kmol} / \mathrm{m}^{3}$. Since the organic was supposedly being contacted with $0.2 \mathrm{kmol} / \mathrm{m}^{3}$ acid solutions, it is probable that an incorrect acid concentration was used in the experiment. The thorium values predicted by SEPHIS were in reasonable agreement with the analytical results.

The McCabe-Thiele diagrams in Figs. 6 and 7 illustrate the thorium behavior in both the cold and hot partitioning column tests. The results from both of the experiments indicate that the thorium should strip easily into the aqueous phase (1BXT), achieving $99.9 \%$ recovery in about four stages. However, the experiment should be repeated to verify that the acid concentration used is correct. The higher acidity in a new test should result in less effective stripping of uranium and thorium than was found in these experiments.

\section{3 Partition-Scrub Column}

The purpose of the partition-scrub operation (the IBS column) is to reextract the uranium from the aqueous thorium product stream without extracting significant amounts of the thorium. With the cold experiment, the calculated and analytical results for thorium compared favorably with each other (Table 9). 
Table 7. Comparison of analytical values with SEPHIS ${ }^{a}$ predictions for cold partition test, experiment 4, 1BX column

\begin{tabular}{|c|c|c|c|c|c|c|}
\hline \multirow[b]{2}{*}{ Sample } & \multicolumn{2}{|c|}{$\mathrm{H}^{+}\left(\mathrm{kmol} / \mathrm{m}^{3}\right)$} & \multicolumn{2}{|c|}{$\mathrm{U}\left(\mathrm{kg} / \mathrm{m}^{3}\right)$} & \multicolumn{2}{|c|}{ Th $\left(\mathrm{kg} / \mathrm{m}^{3}\right)$} \\
\hline & Analysis & SEPHIS & Analysis & SEPHIS & Analysis & SEPHIS \\
\hline $1 \mathrm{BXT}-3-1^{b}$ & 0.22 & 0.21 & 0.109 & 0.113 & 34.4 & 32.6 \\
\hline $1 B U-3-1^{c}$ & 0.05 & 0.03 & 0.530 & 0.970 & 7.84 & 8.16 \\
\hline $1 \mathrm{BXT}-3-2$ & 0.22 & 0.21 & 0.223 & 0.318 & 10.4 & 11.0 \\
\hline $1 B U-3-2$ & 0.06 & 0.03 & 0.413 & 0.747 & 0.82 & 0.41 \\
\hline $1 B X T-3-3$ & 0.22 & 0.21 & 0.244 & 0.600 & 1.40 & 0.58 \\
\hline $1 B U-3-3$ & 0.05 & 0.02 & 0.259 & 0.324 & 0.049 & 0.003 \\
\hline $1 B \times T-3-4$ & 0.22 & 0.20 & 0.232 & 0.286 & 0.035 & 0.004 \\
\hline $1 B U-3-4$ & 0.05 & 0.02 & 0.139 & 0.122 & 0.011 & $<0.001$ \\
\hline $1 B X T-3-5$ & 0.22 & 0.20 & 0.154 & 0.109 & 0.015 & $<0.001$ \\
\hline $1 \mathrm{BU}-3-5$ & 0.05 & 0.02 & 0.075 & 0.045 & 0.005 & $<0.001$ \\
\hline $1 \mathrm{BXT}-3-6$ & 0.22 & 0.20 & 0.074 & 0.040 & 0.006 & $<0.001$ \\
\hline $1 B U-3-6$ & 0.05 & 0.02 & 0.032 & 0.016 & 0.002 & $<0.001$ \\
\hline
\end{tabular}

${ }_{b}^{a}$ SEPHIS predictions at $20^{\circ} \mathrm{C}$.

Aqueous phase.

Organic phase. 
Table 8. Comparison of analytical values with SEPHIS ${ }^{\text {a }}$ predictions for hot partition test, experiment 14, 1BX column

\begin{tabular}{|c|c|c|c|c|c|c|}
\hline \multirow[b]{2}{*}{ Sample } & \multicolumn{2}{|c|}{$\mathrm{H}^{+}\left(\mathrm{kmol} / \mathrm{m}^{3}\right)$} & \multicolumn{2}{|c|}{$U\left(\mathrm{~kg} / \mathrm{m}^{3}\right)$} & \multicolumn{2}{|c|}{$\mathrm{Th}\left(\mathrm{kg} / \mathrm{m}^{3}\right)$} \\
\hline & Analysis & $\overline{\text { SEPHIS }}$ & Analysis & SEPHIS & Analysis & SEPHIS \\
\hline $1 \mathrm{BXT}-1^{\mathrm{b}}$ & 0.25 & 0.44 & 0.162 & 0.077 & 26.94 & 24.21 \\
\hline $1 \mathrm{BU}-1^{\mathrm{C}}$ & - & 0.08 & 0.687 & 0.486 & 6.00 & 6.88 \\
\hline $1 \mathrm{BXT}-2$ & 0.12 & 0.26 & 0.623 & 0.203 & 7.68 & 9.25 \\
\hline $1 \mathrm{BU}-2$ & 0.04 & 0.04 & 0.398 & 0.344 & 0.378 & 0.367 \\
\hline $1 \mathrm{BXT}-3$ & 0.06 & 0.22 & 0.490 & 0.314 & 0.740 & 0.517 \\
\hline $1 B U-3$ & 0.04 & 0.02 & 0.132 & 0.122 & 0.007 & 0.002 \\
\hline $1 \mathrm{BXT}-4$ & 0.06 & 0.21 & 0.221 & 0.124 & 0.010 & 0.004 \\
\hline $1 \mathrm{BU}-4$ & 0.04 & 0.02 & 0.0120 & 0.035 & $<0.001$ & $<0.001$ \\
\hline $1 \mathrm{BXT}-5$ & 0.07 & 0.20 & 0.019 & 0.036 & 0.002 & $<0.001$ \\
\hline $1 \mathrm{BU}-5$ & 0.04 & 0.02 & 0.0011 & 0.010 & $<0.001$ & $<0.001$ \\
\hline $1 \mathrm{BXT}-6$ & 0.07 & 0.20 & 0.0054 & 0.010 & $<0.001$ & $<0.001$ \\
\hline $1 B U-6$ & 0.04 & 0.02 & 0.0011 & 0.0030 & $<0.001$ & $<0.001$ \\
\hline
\end{tabular}

$\mathrm{b}_{\mathrm{b}}^{\mathrm{S}}$ SEPHIS predictions at $35^{\circ} \mathrm{C}$.

Aqueous phase.

Organic phase. 
ORNL DWG 79-1771R

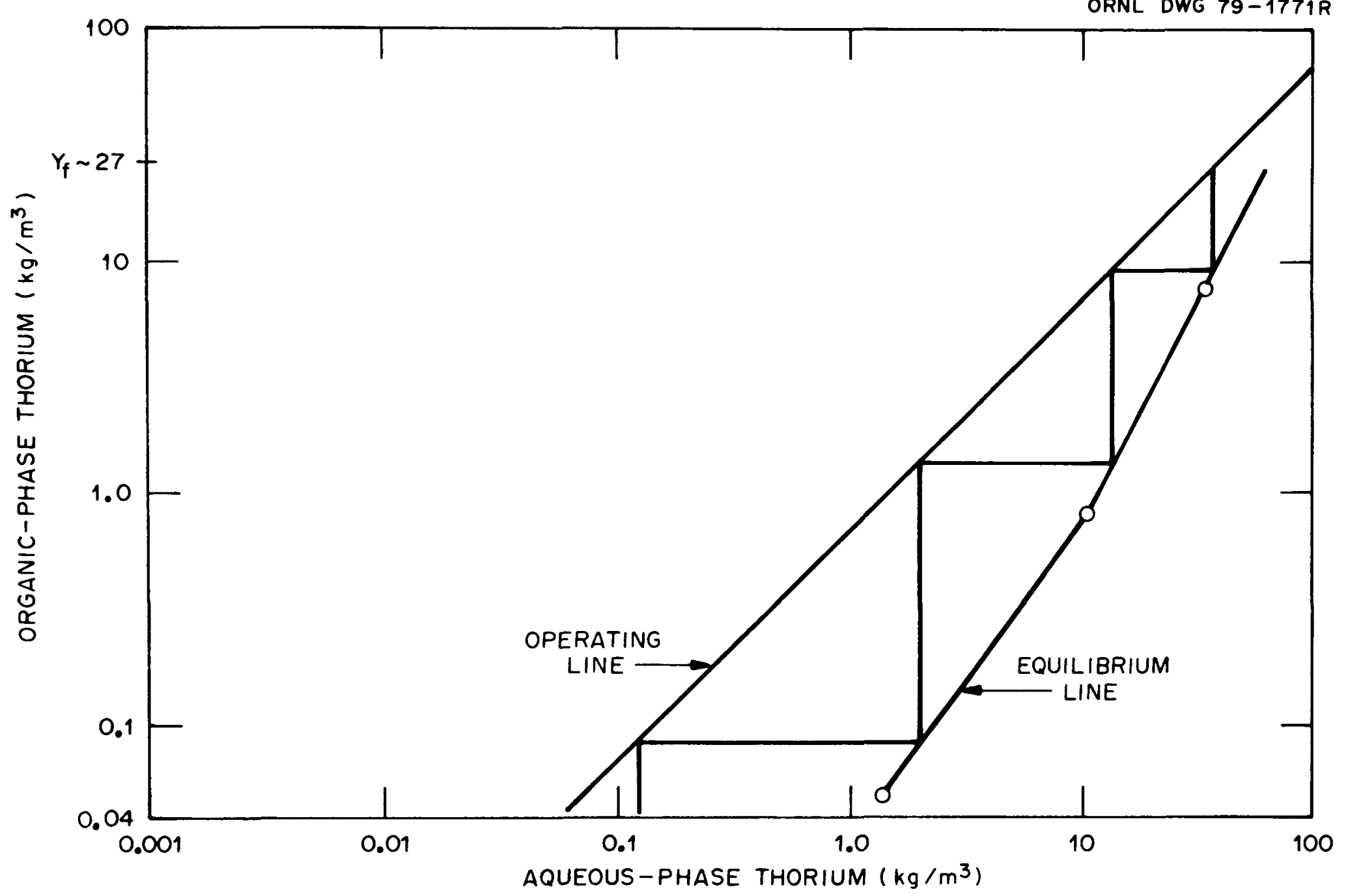

Fig. 6. McCabe-Thiele diagram for cold partition test, experiment 4, $1 \mathrm{BX}$ column. 


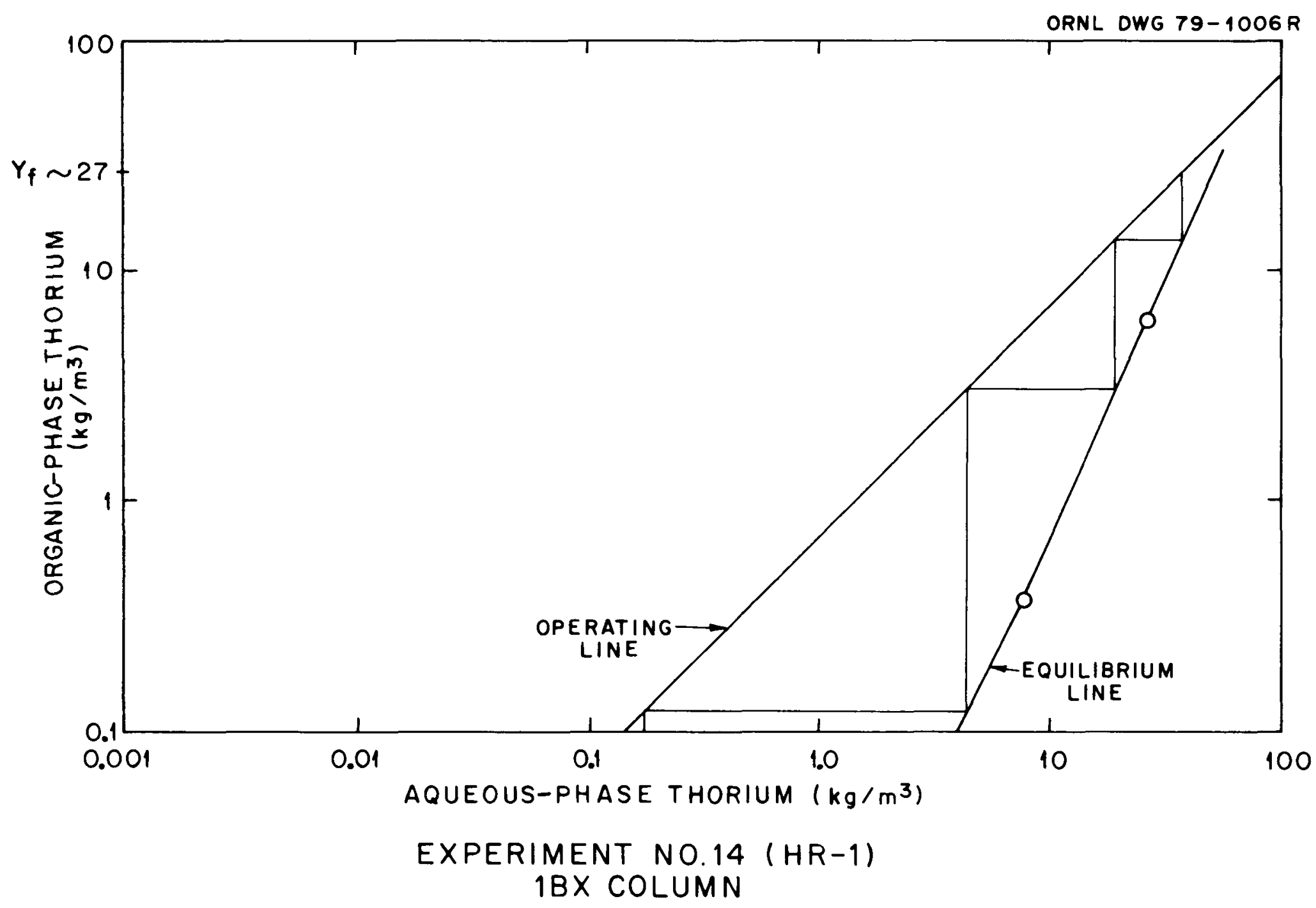

Fig. 7. McCabe-Thiele diagram for hot partition test, experiment 14, $1 \mathrm{BX}$ column. 
Table 9. Comparison of analytical values with SEPHIS ${ }^{a}$ predictions for cold partition-scrub test, experiment 5, 1BS column

\begin{tabular}{|c|c|c|c|c|c|c|}
\hline \multirow[b]{2}{*}{ Sample } & \multicolumn{2}{|c|}{$\mathrm{H}^{+}\left(\mathrm{kmol} / \mathrm{m}^{3}\right)$} & \multicolumn{2}{|c|}{$\mathrm{U}\left(\mathrm{kg} / \mathrm{m}^{3}\right)$} & \multicolumn{2}{|c|}{$\operatorname{Th}\left(\mathrm{kg} / \mathrm{m}^{3}\right)$} \\
\hline & Analysis & $\overline{\text { SEPHIS }}$ & Analysis & $\overline{\text { SEPHIS }}$ & Analysis & SEPHIS \\
\hline $1 \mathrm{BSU}-3-1^{\mathrm{b}}$ & 0.08 & 0.04 & 0.112 & 0.313 & 12.7 & 14.8 \\
\hline $1 B T-3-1^{C}$ & 0.33 & 0.29 & 0.029 & 0.030 & 37.9 & 36.6 \\
\hline $1 \mathrm{BSU}-3-2$ & 0.08 & 0.04 & 0.041 & 0.071 & 10.3 & 11.9 \\
\hline $1 \mathrm{BT}-3-2$ & 0.31 & 0.27 & 0.012 & 0.0071 & 34.3 & 35.8 \\
\hline $1 \mathrm{BSU}-3-3$ & 0.08 & 0.04 & 0.016 & 0.017 & 8.65 & 9.54 \\
\hline $1 B T-3-3$ & 0.29 & 0.26 & 0.0047 & 0.0018 & 32.8 & 32.7 \\
\hline $1 B S U-3-4$ & 0.07 & 0.04 & 0.0057 & 0.0041 & 4.69 & 7.69 \\
\hline $1 B T-3-4$ & 0.28 & 0.25 & 0.0020 & 0.0005 & 30.6 & 30.2 \\
\hline $1 B S U-3-5$ & 0.07 & 0.04 & 0.0031 & 0.0011 & 6.07 & 6.25 \\
\hline $1 \mathrm{BT}-3-5$ & 0.26 & 0.24 & 0.0010 & 0.0001 & 28.5 & 28.2 \\
\hline $1 B S U-3-6$ & 0.07 & 0.03 & 0.0015 & 0.0003 & 4.74 & 5.14 \\
\hline $1 \mathrm{BT}-3-6$ & 0.26 & 0.22 & 0.0005 & 0.0001 & 26.9 & 26.6 \\
\hline
\end{tabular}

${ }^{a}$ SEPHIS predictions at $20^{\circ} \mathrm{C}$.

Organic phase.

${ }^{\mathrm{c}}$ Aqueous phase. 
In the hot experiment, similar comparisons (Table 10) were seen, except that all but the first value for thorium found in the aqueous phase were a factor of 4 too low, compared with both SEPHIS-MOD 4 and the cold experiment. This suggests these low values are the result of some analytical problem. The aqueous acidity in the hot run appeared to be higher than specified, but still within reason. There was good agreement between the urantum measurements and the SEPHIS-MOD4 predictions.

The McCabe-Thiele plot for the behavior of the uranium is shown in Fig. 8. In spite of the slightly higher acidity, it is apparent that the reextraction of the uranium into the organic phase (IBSU) will require a large number of stages under these conditions. The experiment with hot feed should be repeated to confirm this result.

\subsection{Strip Column}

A uranium stripping operation (the $1 \mathrm{C}$ column) is necessary for the transfer of the uranium from the organic phase into the final aqueous phase. In this flowsheet the loaded organic was contacted with six successive portions of $0.01 \mathrm{kmol} / \mathrm{m}^{3} \mathrm{HNO}_{3}$. This should have rapidly stripped the uranium and the nitric acid from the organic, resulting in $0.01 \mathrm{kmol} / \mathrm{m}^{3} \mathrm{HNO}_{3}$ in the final aqueous solution.

In both the cold (Table 11) and the hot (Table 12) experiments, incomplete uranium stripping was indicated. The experimental analyses indicated $0.12 \mathrm{kmol} / \mathrm{m}^{3} \mathrm{HNO}_{3}$ in each stage for the cold run. An improper acid solution may have been used for the experiment, or the analytical results may be inaccurate. The acidity was $0.03 \mathrm{kmol} / \mathrm{m}^{3}$ in the hot run. This is not significantly different from $0.01 \mathrm{kmol} / \mathrm{m}^{3}$ to be a problem.

The SEPHIS program and other experience indicates that the uranium can be completely stripped from the organic with 0.01 $\mathrm{kmol} / \mathrm{m}^{3} \mathrm{HNO}_{3}$. Since this experiment shows that incomplete stripping is inevitable with either $0.12 \mathrm{kmol} / \mathrm{m}^{3}$ or $0.03 \mathrm{kmol} / \mathrm{m}^{3} \mathrm{HNO}_{3}$ this flowsheet test should be repeated with known $0.01 \mathrm{kmol} / \mathrm{m}^{3} \mathrm{HNO}_{3}$ to verify that the conditions are appropriate. 
Table 10. Comparison of analytical values with SEPHIS ${ }^{a}$ predictions for hot partition-scrub test, experiment 15, 1BS column

\begin{tabular}{|c|c|c|c|c|c|c|}
\hline \multirow[b]{2}{*}{ Sample } & \multicolumn{2}{|c|}{$\mathrm{H}^{+}\left(\mathrm{kmol} / \mathrm{m}^{3}\right)$} & \multicolumn{2}{|c|}{$\mathrm{U}\left(\mathrm{kg} / \mathrm{m}^{3}\right)$} & \multicolumn{2}{|c|}{$\operatorname{Th}\left(\mathrm{kg} / \mathrm{m}^{3}\right)$} \\
\hline & Analysis & SEPHIS & Analysis & SEPHIS & Analysis & SEPHIS \\
\hline $1 \mathrm{BSU}-1^{\mathrm{b}}$ & 0.06 & 0.04 & 0.470 & 0.579 & 13.0 & 12.2 \\
\hline $1 \mathrm{BT}-1^{\bar{C}}$ & 0.40 & 0.24 & 0.074 & 0.087 & 39.2 & 41.0 \\
\hline $1 \mathrm{BSU}-2$ & 0.06 & 0.04 & 0.198 & 0.183 & 10.5 & 10.2 \\
\hline $1 \mathrm{BT}-2$ & 0.39 & 0.22 & 0.033 & 0.028 & $9.95^{\mathrm{d}}$ & 37.8 \\
\hline $1 B S U-3$ & 0.06 & 0.04 & 0.083 & 0.059 & 8.95 & 8.39 \\
\hline $1 \mathrm{BT}-3$ & 0.34 & 0.21 & 0.0145 & 0.0096 & $9.18^{\mathrm{d}}$ & 35.1 \\
\hline $1 B S U-4$ & 0.06 & 0.04 & 0.037 & 0.019 & $7.12 \mathrm{~d}$ & 6.94 \\
\hline $1 \mathrm{BT}-4$ & 0.34 & 0.20 & 0.0071 & 0.0034 & $8.54^{\mathrm{d}}$ & 32.9 \\
\hline $1 B S U-5$ & 0.07 & 0.03 & 0.017 & 0.0066 & $6.28 \mathrm{~d}$ & 5.77 \\
\hline $1 \mathrm{BT}-5$ & 0.33 & 0.19 & 0.0032 & 0.0013 & $7.74^{\mathrm{d}}$ & 31.0 \\
\hline $1 \mathrm{BSU}-6$ & 0.07 & 0.03 & 0.0087 & 0.0024 & $5.37 \mathrm{~d}$ & 4.83 \\
\hline $1 B T-6$ & 0.31 & 0.18 & 0.0018 & 0.0005 & $7.96^{\mathrm{d}}$ & 29.4 \\
\hline
\end{tabular}

${ }^{a}$ SEPHIS predictions at $35^{\circ} \mathrm{C}$.

Organic phase.

Aqueous phase.

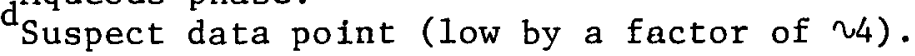


ORNL DWG 79-804R

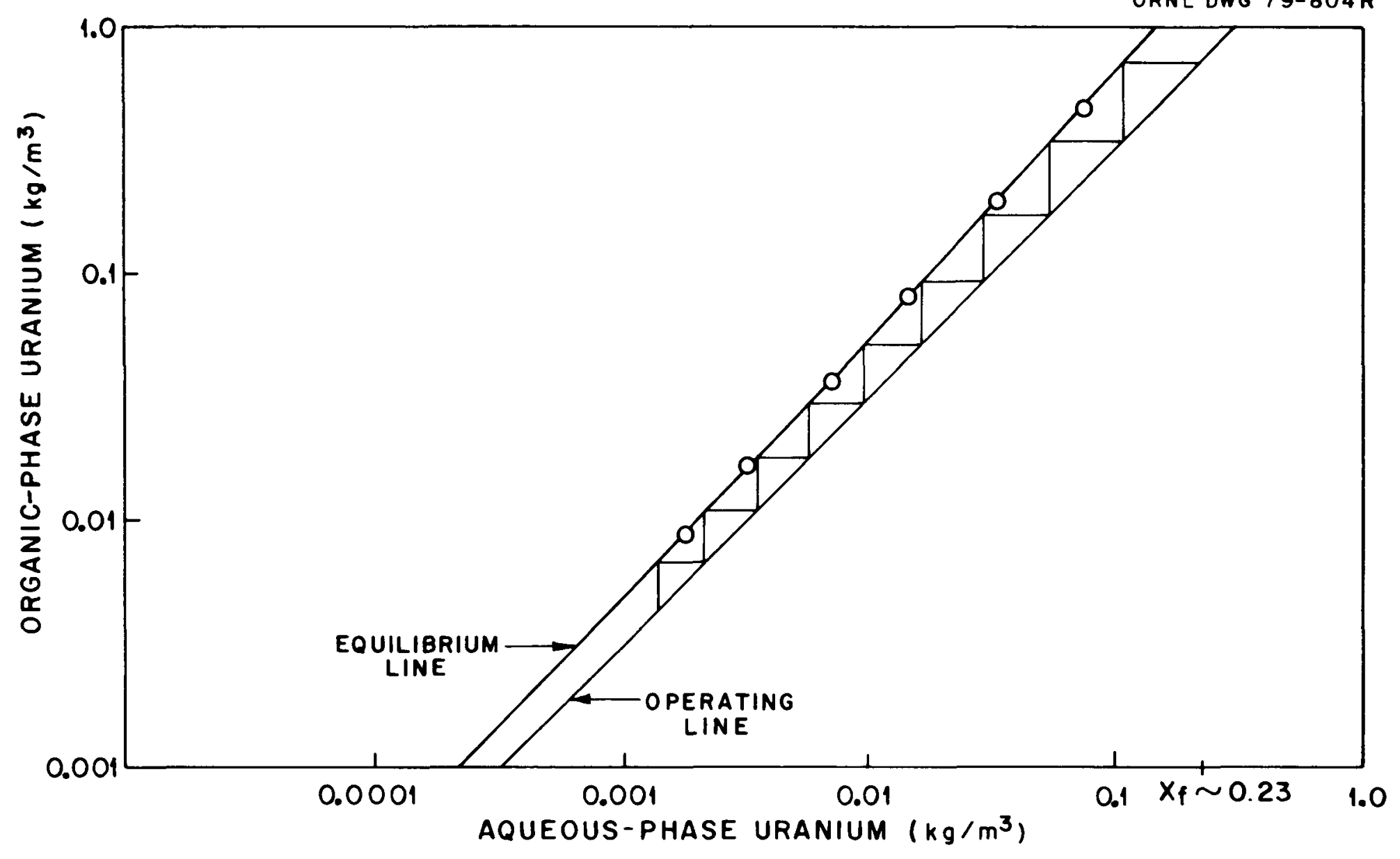

\section{EXPERIMENT NO. $15(H R-1)$ \\ 1BS COLUMN}

Fig. 8. McCabe-Thiele diagram for hot partition-scrub test, experiment $15,1 B S$ column. 
Table 11. Comparison of analytical values with SEPHIS ${ }^{a}$ predictions for cold strip test, experiment $6,1 \mathrm{C}$ column

\begin{tabular}{|c|c|c|c|c|}
\hline \multirow[b]{2}{*}{ Sample } & \multicolumn{2}{|c|}{$\mathrm{H}^{+}\left(\mathrm{kmol} / \mathrm{m}^{3}\right)$} & \multicolumn{2}{|c|}{$\mathrm{U}\left(\mathrm{kg} / \mathrm{m}^{3}\right)$} \\
\hline & Ana1ysis & SEPHIS & Analysis & $\overline{\text { SEPHIS }}$ \\
\hline $\begin{array}{l}1 C U-3-1^{b} \\
1 C W-3-1^{c}\end{array}$ & $\begin{array}{l}0.12 \\
0.04\end{array}$ & $\begin{array}{l}0.09 \\
0.01\end{array}$ & $\begin{array}{l}1.08 \\
0.371\end{array}$ & $\begin{array}{l}2.06 \\
0.627\end{array}$ \\
\hline $\begin{array}{l}1 C U-3-2 \\
1 C W-3-2\end{array}$ & $\begin{array}{l}0.12 \\
0.04\end{array}$ & $\begin{array}{r}0.03 \\
<0.01\end{array}$ & $\begin{array}{l}0.792 \\
0.240\end{array}$ & $\begin{array}{l}2.31 \\
0.209\end{array}$ \\
\hline $\begin{array}{l}1 \mathrm{CU}-3-3 \\
1 \mathrm{CW}-3-3\end{array}$ & $\begin{array}{l}0.12 \\
0.04\end{array}$ & $\begin{array}{r}0.01 \\
<0.01\end{array}$ & $\begin{array}{l}0.529 \\
0.165\end{array}$ & $\begin{array}{l}1.01 \\
0.025\end{array}$ \\
\hline $\begin{array}{l}1 \mathrm{CU}-3-4 \\
1 \mathrm{CW}-3-4\end{array}$ & $\begin{array}{l}0.12 \\
0.04\end{array}$ & $\begin{array}{r}0.01 \\
<0.01\end{array}$ & $\begin{array}{l}0.363 \\
0.101\end{array}$ & $\begin{array}{l}0.131 \\
0.0012\end{array}$ \\
\hline $\begin{array}{l}1 \mathrm{CU}-3-5 \\
1 \mathrm{CW}-3-5\end{array}$ & $\begin{array}{l}0.12 \\
0.04\end{array}$ & $\begin{array}{r}0.01 \\
<0.01\end{array}$ & $\begin{array}{l}0.223 \\
0.067\end{array}$ & $\begin{array}{r}0.0061 \\
<0.0001\end{array}$ \\
\hline $\begin{array}{l}1 \mathrm{CU}-3-6 \\
1 \mathrm{CW}-3-6\end{array}$ & $\begin{array}{l}0.12 \\
0.04\end{array}$ & $\begin{array}{r}0.01 \\
<0.01\end{array}$ & $\begin{array}{l}0.136 \\
0.042\end{array}$ & $\begin{array}{r}0.0002 \\
<0.0001\end{array}$ \\
\hline
\end{tabular}

${ }^{a}$ SEPHIS predictions at $20^{\circ} \mathrm{C}$.

Aqueous phase.

Organic phase. 
Table 12. Comparison of analytical values with SEPHIS ${ }^{\text {a }}$ predictions for hot strip test, experiment 16, 1C column

\begin{tabular}{|c|c|c|c|c|c|c|}
\hline \multirow[b]{2}{*}{ Sample } & \multicolumn{2}{|c|}{$\mathrm{H}^{+}\left(\mathrm{kmol} / \mathrm{m}^{3}\right)$} & \multicolumn{2}{|c|}{$\mathrm{U}\left(\mathrm{kg} / \mathrm{m}^{3}\right)$} & \multicolumn{2}{|c|}{ Th $\left(\mathrm{kg} / \mathrm{m}^{3}\right)$} \\
\hline & Analysis & $\overline{\text { SEPHIS }}$ & Analysis & SEPHIS & Analysis & SEPHIS \\
\hline $1 \mathrm{CU}-1^{\mathrm{b}}$ & 0.05 & 0.04 & 0.661 & 0.985 & 3.26 & 0.144 \\
\hline $1 C W-1^{C}$ & - & $<0.01$ & 0.746 & 0.016 & 0.108 & 0.001 \\
\hline $1 \mathrm{CU}-2$ & 0.03 & 0.01 & 0.506 & 0.043 & 0.737 & 0.001 \\
\hline $1 \mathrm{CW}-2$ & - & $<0.01$ & - & $<0.0001$ & - & - \\
\hline $1 \mathrm{CU}-3$ & 0.03 & 0.01 & 0.085 & 0.0001 & 0.221 & - \\
\hline $1 \mathrm{CW}-3$ & - & $<0.01$ & 0.0018 & $<0.0001$ & 0.002 & - \\
\hline $1 \mathrm{CU}-4$ & 0.03 & 0.01 & 0.010 & 0.0001 & 0.037 & - \\
\hline $1 \mathrm{CW}-4$ & 0.04 & $<0.01$ & 0.0008 & $<0.0001$ & $<0.001$ & - \\
\hline $1 \mathrm{CU}-5$ & 0.03 & 0.01 & 0.0034 & - & 0.015 & - \\
\hline $1 \mathrm{CW}-5$ & 0.04 & $<0.01$ & 0.0002 & - & $<0.001$ & - \\
\hline $1 \mathrm{CU}-6$ & 0.03 & 0.01 & 0.0077 & - & 0.019 & - \\
\hline $1 \mathrm{CW}-6$ & 0.04 & $<0.01$ & 0.0042 & - & $<0.001$ & - \\
\hline
\end{tabular}

${ }^{a}$ SEPHIS predictions at $30^{\circ} \mathrm{C}$.

b Aqueous phase.

Corganic phase. 


\subsection{Fission Product Distribution}

The distribution of measurable fission products was studied as an adjunct to the foregoing flowsheet tests. The fuel used in these experiments was of the Fort St. Vrain HTGR type and was irradiated in the Peach Bottom Reactor for 512 effective full-power days (EFPD) over the period Jan. 7, 1972 to Oct. 31, 1974. The radioactivity measurements and ORIGEN nuclide values were corrected for decay to 0ct. 1 , 1977.

The primary purpose for the first test was to get $U, T h$, and $\mathrm{HNO}_{3}$ data and develop the experimental procedures. The sequential tests followed each other by a period of a week or so, and the solvent damage may have been appreciable. This would prevent one from obtaining very high decontamination factors in these tests. In future tests, the emphasis will shift to the fission product behavior, and the contact times will be shortened. Since analyzing the samples for the uranium, thorium and acid concentrations provided the primary means for evaluating the flowsheet parameters; only small portions of the samples, if any, were available for plutonium and radiochemical analyses. A sample aliquot was first gamma-scanned. It was then analyzed for plutonium and those radionuclides present in a concentration sufficiently above background to be measurable within the analytical method's range of reliability.

The accountability and distribution of plutonium in the hot experiments are listed in Table 13. Generally, the plutonium accountability is good, ranging from $96 \%$ in the partition column experiment to $282 \%$ in the partition-scrub column experiment. Accountability for the strip column could not be calculated because the feed solution was not analyzed for plutonium. The plutonium distribution between the phases is readily apparent when viewed graphically in Fig. 9. The behavior of the plutonium during the tests was similar to the uranium and thorium behavior.

The distribution of the heavy metals and radionuclides in experiment 13, the extraction column test, is shown in Fig. 10. The decontamination factors obtained in the experiments were poor, averaging 210 overal1. Iodine-129 was the only fission product divided about equally between phases. Although some of the fission product radionuclides, 
Table 13. Distribution and accountability of the plutonium in the hot experiments

\begin{tabular}{|c|c|c|c|c|c|c|}
\hline \multirow[b]{3}{*}{ Test } & \multirow{3}{*}{$\begin{array}{c}\text { In } \\
\text { Total } \\
\text { (MBq) }\end{array}$} & \multicolumn{4}{|c|}{ Out } & \multirow[b]{3}{*}{$\%$ recovery } \\
\hline & & \multicolumn{2}{|c|}{ Organic } & \multicolumn{2}{|c|}{ Aqueous } & \\
\hline & & $(\mathrm{MBq})$ & $(\%)$ & $(\mathrm{MBq})$ & $(\%)$ & \\
\hline Extraction & 48.0 & 41.8 & 95.9 & 1.77 & 4.1 & 91.0 \\
\hline Partition & 33.0 & 23.3 & 73.8 & 8.30 & 26.2 & 96.0 \\
\hline $\begin{array}{l}\text { Partition- } \\
\text { scrub }\end{array}$ & 7.87 & 2.77 & 43.0 & 3.67 & 57.0 & 81.8 \\
\hline Strip & - & 5.563 & 34.6 & 1.06 & 65.4 & - \\
\hline
\end{tabular}


ORNL OWG 79-1770

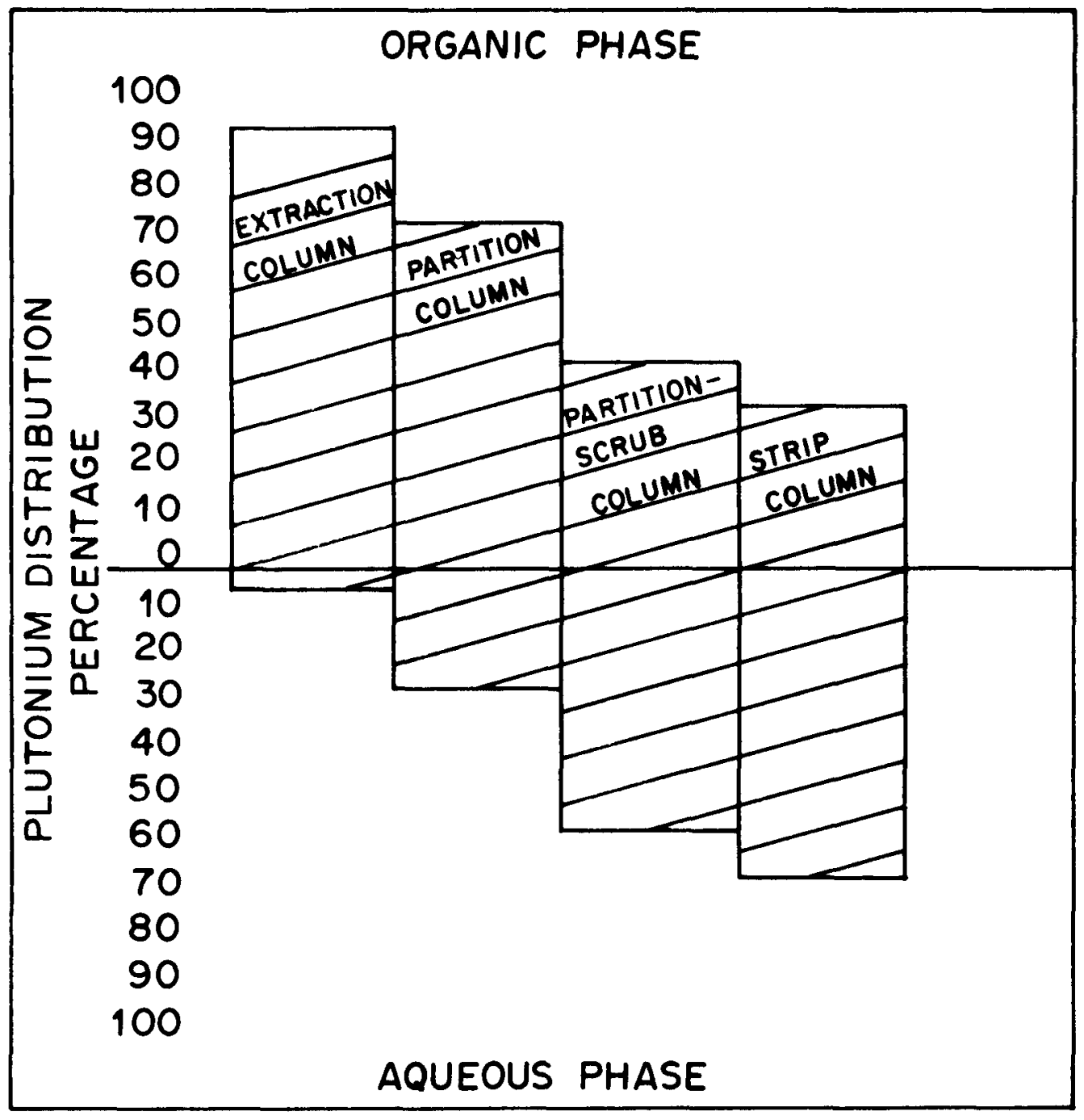

Fig. 9. Plutonium distribution between the organic and aqueous phases. 
ORNL DWG 79-?768R

ORGANIC PHASE

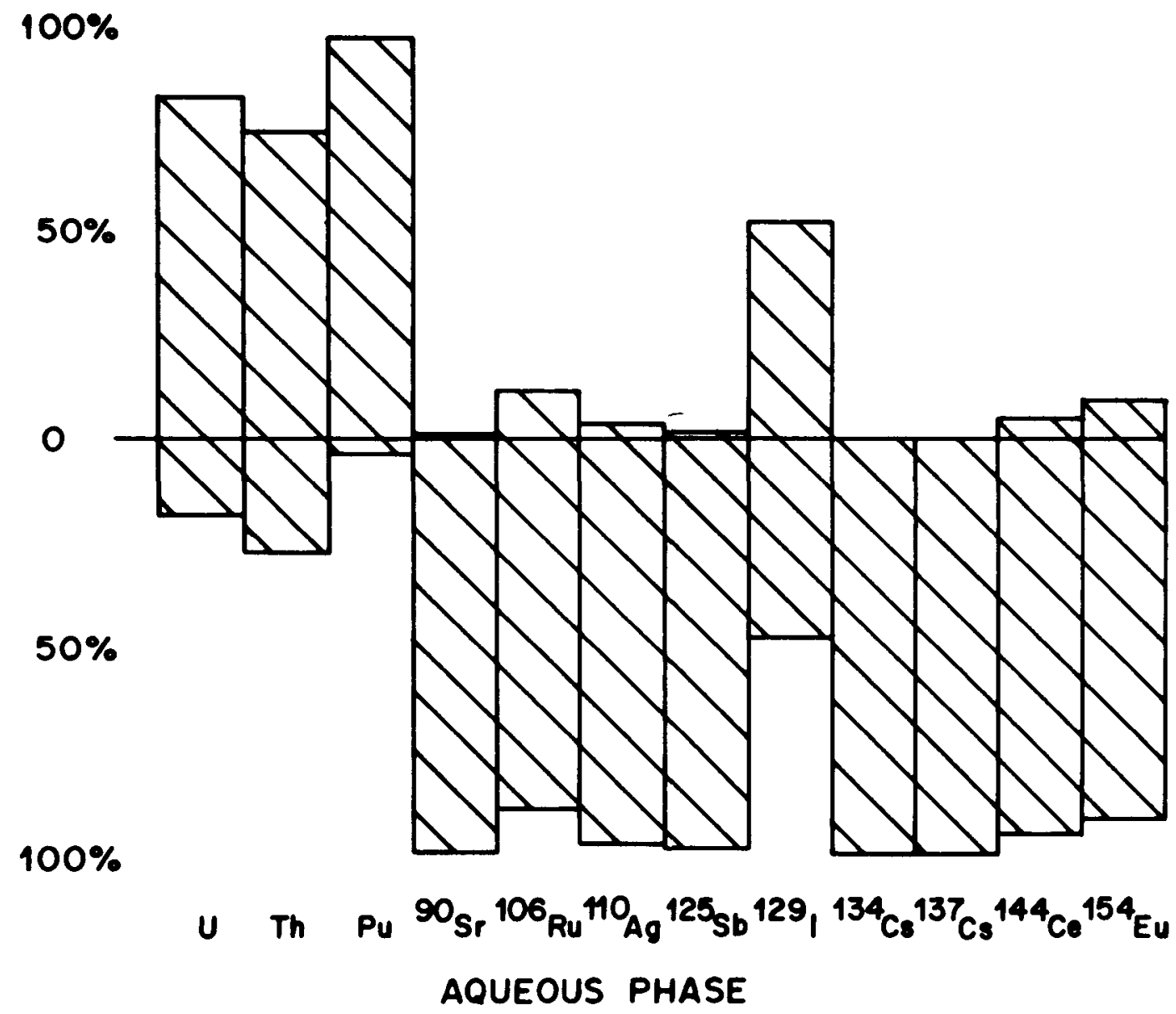

Fig. 10. Extraction column (experiment 13, 1A column): heavy-meta1 and radionuclide distribution (first stage). 
such as ${ }^{106} \mathrm{Ru}_{\mathrm{u}}$ and ${ }^{154} \mathrm{E}_{\mathrm{u}}$, extracted into the $30 \% \mathrm{TBP} / \mathrm{NPH}$, greater than $99 \%$ of the others remained with the aqueous phase.

Figure 11 shows the radionuclide distribution in the partition column test. The column was designed to cause the thorium to transfer into the aqueous phase and leave the uranium in the solvent. Most of the ${ }^{106} \mathrm{Ru}$ and ${ }^{129} \mathrm{I}$ remained in the organic phase, while the other fission products followed the thorium into the aqueous phase.

The partition-scrub column was designed for reextracting the uranium into the solvent with minimal carryover of thorium. This is illustrated in Fig. 12, although the percentage of unextracted uranium is higher than desired. Iodine-129 is the only fission product showing appreciable ( $25 \%$ ) reextraction.

Most of the samples representing the strip column experiment were consumed in the analysis for uranium, thorium, and acid. Iodine-129 was measured in both phases, with $82 \%$ found remaining in the organic layer. Strontium-90 was the other fission product measured in both phases, with $99 \%$ stripped into the dilute nitric acid solution.

\section{EVALUATION OF THE PERFORMANCE OF THE SEPHIS-MOD4 CODE}

Comparisons between the results from batch Thorex solvent extraction flowsheet tests and predictions using the SEPHIS-MOD4 program ranged from reasonably good to very poor. Internal inconsistencies and poor mass balances of some of the experimental results prevented verification of the SEPHIS-MOD4 code In this experimental series.

Using the SEPHIS program in these Thorex process comparisons did bring to light an unforeseen peculiartty in the program. Calculations for the conditions well past the point of saturation of the organic yielded negative distribution coefficients for the Thorex process using the SEPHIS code. The cause of the problem was investigated, and corrective steps have been taken.

\section{CONCLUSIONS AND RECOMMENDATIONS}

In summary, the data developed during the first series of hotcell tests of the first cycle Thorex flowsheet allow some conclusions. Cold tests and a test of the Thorex flowsheet with irradiated hot fuel indicated the following: 


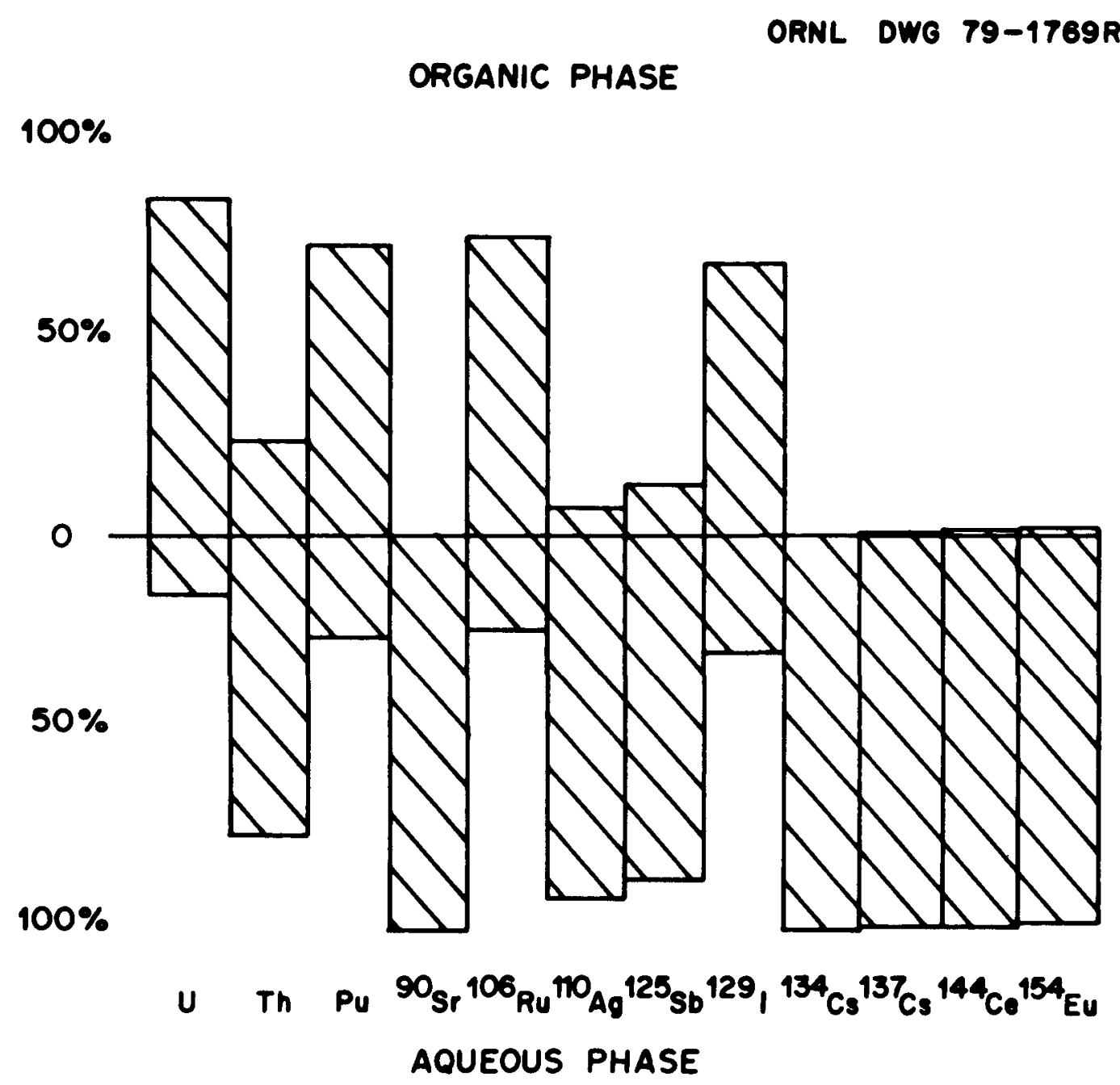

Fig. 11. Partition column (experiment 14, 1BX column): heavy-meta1 and radionuclide distribution (first stage). 


\section{ORGANIC PHASE}

$100 \%$

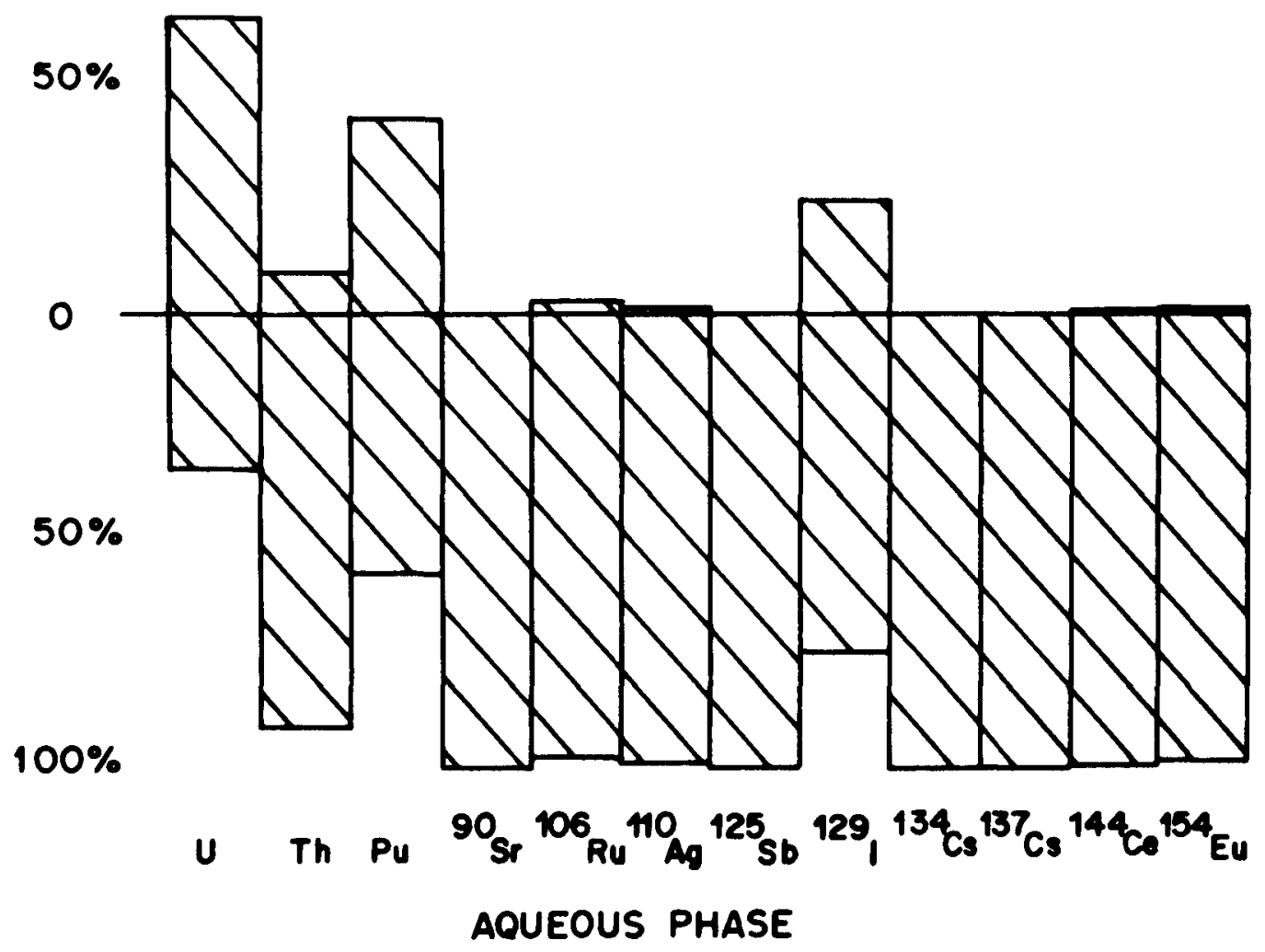

Fig. 12. Partition-scrub column (experiment 15, 1BS column): heavymetal and radionuclide ditribution (first stage). 
1. The proposed operating conditions in the $1 \mathrm{~A}$ extraction section are probably correct. Most of the thorium (99.9\%) should be extracted in five to seven stages. The experiment with the hot fuel should be repeated at a higher acidity to better represent the expected conditions in the column.

2. The partition column (1BX) conditions were studied in one cold test and one hot test. The thorium stripped easily, indicating that a $99.9 \%$ recovery is possible in about four stages. The degree of uranium separation cannot be conclusively determined. This is due primary to the nature of crosscurrent batch testing, but the possible use of a strip solution of improper acidity and the poor mass balances also contributed. Further testing with countercurrent flow is necessary to test the uranium behavior in this portion of the flowsheet.

3. The cold and hot experiments to test the partition-scrub column (IBX) indicate adequate thorium behavior. The reextraction of the uranium seems to be possible, but cannot be assured with these tests. Additional tests of these conditions are needed to more closely define the uranium behavior.

4. Incomplete stripping of the uranium, shown by both the hot and cold experiments for the $1 \mathrm{C}$ column, indicates that the tested flowsheet conditons probably will not work. Further tests should be made since practical experience and the SEPHIS MOD4 program Indicate that these conditions are suitable.

\section{ACKNOWLEDGMENTS}

The authors gratefully acknowledge the guidance and suggestions received from A. P. Malinauskas, K. J. Notz, O. K. Tallent, C. F. Coleman, J. H. Shaffer, and W. E. Unger; the typing of the drafts and final copy by C. A. Proaps; the editing by C. H. Shappert and M. G. Stewart; and the analytical services provided by the members of the Analytical Chemistry Division. 


\section{REFERENCES}

1. A. D. Mitche11, Modification of the SEPHIS-MOD4 Computer Program to Simulate the Thorex Solvent Extraction Process, ORNL/TM-6825 (December 1979).

2. S. B. Watson and R. H. Ralney, Modeling the Effect of Temperature on Thorium and Nitric Acid Extraction and the Formation of Third Phase for Modification of the SEPHIS-THOREX Computer Program, $\overline{\mathrm{ORNL}}$; $\overline{\mathrm{DS}} / \mathrm{TM} \overline{\mathrm{M}} \mathrm{69}$ (May 1979).

3. A. J. Weinberger, J. L. Marley, and D. A. Costanzo, A Solvent Extraction Study of the Thorium Nitrate, Nitric Acid, Tributry1 Phosphate/Dodecane System, ORNL/TM-7240 (May 1980).

4. M. J. Be11, ORIGEN - The ORNL Isotope Generation and Depletion Code, ORNL-4628(May $\overline{1973) . ~}$

5. C. L. Fitzgerald, Head-end Reprocessing Studies with Irradiated HTGR Fuel from Test Element FTE-16, ORNL/TM-7030 (in preparation). 
ORNL/TM-7108

Dist. Category

UC-86 (App1ied)

INTERNAL DISTRIBUTION

1. S. M. Babcock

2. J. E. Bigelow

3. J. 0. Blomeke

4-8. W. D. Burch

9. E. D. Collins

10. D. J. Crouse

11. R. D. Ehrlich

12. R. L. Fellows

13. J. H. Goode

14. W. S. Groenier

15. B. A. Hannaford

16. R. T. Jubin

17. P. R. Kasten

18. M. V. Keigan

19. L. J. King

20. C. H. LaMaster

21-25. C. E. Lamb

26. R. E. Leuze

27. R. S. Lowrie

28. J. C. Mailen

29. A. P. Malinauskas

30. J. F. Mincey
31-35. A. D. Mitche11

36. R. E. Norman

37. R. L. Philippone

38. R. H. Powell

39. D. J. Pruett

40-44. R. J. Shannon

45-49. C. H. Shappert

50. R. G. Stacy

51. D. W. Swindle

52. O. K. Tallent

53. W. E. Unger

54-58. V. C. A. Vaughen

59. D. W. Williams

60. R. G. Wymer

61. 0. 0. Yarbro

62-63. Laboratory Records

64. Laboratory Records, RC

65. ORNL Patent Office

66. Nuclear Safety Information Center

EXTERNAL DISTRIBUTION

67-68. W. W. Ballard, Nuclear Fuel Cycle Division, Office of LightWater Reactors, U.S. Department of Energy, Washington, D.C. 20545

69. D. K. Lorenzo, Nuclear Fuel Cycle Division, Office of LightWater Reactors, U.S. Department of Energy, Washington, D.C. 20545

70. Office of Assistant Manager for Energy Research and Development, U.S. Department of Energy - Oak Ridge Operations, Oak Ridge, Tennessee 37830

71-156. Given distribution as shown in TID-4500 under UC-86, Consolidated Fuel Reprocessing Category (Applied) 